Article

\title{
Green Densities: Accessible Green Spaces in Highly Dense Urban Regions-A Comparison of Berlin and Qingdao
}

\author{
Olaf Mumm $^{1, *}{ }^{\oplus}$, Ryan Zeringue ${ }^{1}$, Nannan Dong ${ }^{2}$ and Vanessa Miriam Carlow ${ }^{1}$ \\ 1 SpACE Lab at ISU-Institute for Sustainable Urbanism, Technische Universität Braunschweig, \\ 38106 Braunschweig, Germany; r.zeringue@tu-braunschweig.de (R.Z.); \\ v.carlow@tu-braunschweig.de (V.M.C.) \\ 2 College of Architecture and Urban Planning, Tongji University, Siping Rd. 1239, Shanghai 200092, China; \\ dongnannan@tongji.edu.cn \\ * Correspondence: o.mumm@tu-braunschweig.de; Tel.: +49-531-391-3537
}

check for updates

Citation: Mumm, O.; Zeringue, R.; Dong, N.; Carlow, V.M. Green Densities: Accessible Green Spaces in Highly Dense Urban Regions-A Comparison of Berlin and Qingdao. Sustainability 2022, 14, 1690. https://doi.org/10.3390/su14031690 Academic Editor: Thomas A. Clark Received: 15 December 2021 Accepted: 27 January 2022 Published: 1 February 2022 Publisher's Note: MDPI stays neutral with regard to jurisdictional claims in published maps and institutional affiliations.

Copyright: (C) 2022 by the authors. Licensee MDPI, Basel, Switzerland. This article is an open access article distributed under the terms and conditions of the Creative Commons Attribution (CC BY) license (https:// creativecommons.org/licenses/by/ $4.0 /)$.

\begin{abstract}
Recreational green spaces are associated with human thriving and well-being. During the ongoing COVID-19 pandemic a spotlight has been shed on the interconnection between access to these spaces, human well-being and social equity. Containment measures enacted in many cities effectively precluded people from reaching distant recreational areas during the pandemic and consequently, recreational areas close to home became particularly important. Urban density is often associated with building or population density with the assumption that if either parameter has a high value, the availability of open (green) space is low. Certain densities are associated with specific spatial qualities. Addressing challenges of sustainable development, a detailed evaluation of density is necessary to allow evidence-based arguments, planning and decision-making. In this study we develop a multi-scale analysis method for quantifying and assessing green infrastructures from settlement unit to building level to reach a differentiated view on density, arguing that density can be organized in different ways achieving very different qualities. For this purpose, we use geospatial-data analysis and in-depth neighborhood studies to compare two cities in Asia and Europe, revealing different ways of organizing density in the built environment and identifying a derivation of approaches for sustainable development in dense urban regions.
\end{abstract}

Keywords: urban density; green density; recreational spaces; green accessibility assessment; building proximity score; urban design solutions; geospatial analytics; sustainability

\section{Introduction}

Recreational open spaces are associated with human thriving and well-being. Where access to open green spaces is limited, concerns of inequality are raised [1,2]. During the ongoing COVID-19 pandemic especially, a spotlight has been shed on the interconnection between access to open spaces, human well-being and social equity [3,4]. Containment measures enacted in many states and cities effectively precluded people from reaching distant recreational areas during the height of the pandemic [5]. Consequently, recreation areas close to home became particularly important [6]. Furthermore, rural spaces were transfigured into places of longing [7-9]. Yet historically, certain planning narratives assumed a dichotomy between "green" versus "built" spaces in European cities, first as an outside or inside [10]. The medieval city was separated from the surrounding rural and dangerous area by defensive walls. Inside the enclosed city, constant growth was accompanied by a significant increase in population and building density and consequently poor living conditions [11]. The Renaissance Garden established a new concept of designed landscape for recreation in addition to nature as a resource in Europe around the late 15 th century. In contrast, the creation of large parks during the Baroque period was an expression of humankind's dominion over nature. The complexes were inaccessible to ordinary citizens and reserved exclusively for the nobility [12]. The English landscape 
garden emerged at the beginning of the 18th century and endeavored to recreate an ideal representation of nature [13]. Publicly accessible parks as we know them today did not appear in Europe until the mid-19th century. They were a response to the increasingly deteriorating living conditions in cities as a result of industrialization [14], including the spread of many highly infectious diseases such as Cholera in the densely inhabited poor urban quarters [15]. In this context, utopian urban concepts avoiding population density such as Ebenezer Howard's Garden City (1898) are also to be understood as a response to the dire living conditions in cities, yet at the same time also sought to counter the inadequacies of countryside life. The self-sufficient settlement units of the garden city movement are characterized by their low building density and the dominance of lush green open spaces and public parks $[16,17]$. Urban expansion plans of many European capitals in the 1920s, such as Berlin, included in the provision of generous public and private green spaces, including forests, parks and allotment gardens, which also served self-sufficiency [18,19].

This contrasts with concepts of early modernism promoting higher density, e.g., Le Corbusier's Ville Radieuse and the idea of the urban landscape amid flowing green spaces $[17,20]$. However, these concepts were also accompanied by the separation of functions throughout the urban area made possible by efficient transportation. This also let rise to the "car-oriented city" [21] in Europe with the end of the Second World War at the latest. In the course of erecting urgently needed housing following the modernist paradigm, the development of public spaces and recreational areas had often been neglected. Green areas merely functioned as stand-off greenery allowing ventilation and lighting, whereas the utilization of the very green spaces themselves was often neglected [22]. On the other hand, concepts such as greenbelts enacted worldwide, saw a concentration of green and open spaces outside the core cities [15]. China's tradition of urban planning can be dated back to the Zhou Dynasty in 1000 B.C. and developed with the walled city a characteristic urban form. The ancient Chinese word of City (Chen) means the city wall. Essential to its tradition are the principles of Chinese geomancy or Fengshui, which, among other things, focus strongly on the relationship of humans with the natural environment [23,24]. Apart from the colonial influences in the first half of the 20th century [23], a shift in planning culture at the level of the entire urban area can be observed starting in the 1950s with the turn to a socialist mode of spatial production following the modernist planning ideals $[25,26]$. The earliest attempts at modern urban planning, including public green systems can be traced back to the late 1920s [27]. Although such projects were hardly realized, some modern residential communities were built in Nanjing, Wuhan and Guangzhou during 1930s [28]. The fast development of industrialization since 1950s in New China has been accompanied by the strong influence of the modern urban planning system from the former Soviet Union, which pays more attention to functional zoning in land use and the hierarchy of the green system for social equality [29]. The new development approach used since the 1990s based on the market system, triggered the strong urban sprawl tendencies in big cities [30]. Green spaces serve not only as an ecological infrastructure for the rapidly growing city, but also as important socio-cultural facilities at the community level in view of the rapid demographic development of the city [31,32].

This brief overview is by no means intended to be a comprehensive review of the city and green infrastructures. Rather, it serves to illustrate how the perception of density is shaped by historical and societal conventions and connotations [33]. Subsequently, certain densities are associated with specific urban space qualities. In that tradition, urban density is often associated with building or population density followed by the assumption that if these two parameters have a high value, then the availability or accessibility of recreational, open and green space is low. However, there are different mechanisms that can be utilized to cope with or manage density. Examples include the vertical structuring of urban functions and green spaces, as in Singapore with complex building designs such as Kampung Admiralty by WOHA [34,35], high-density high-rise public housing with vertically structured public spaces [36] or projects in Vietnam by VTN Architects [37] such as Diamond Lotus [38]. In a European context, the architectural projects of offices such as MVRDV with 
e.g., the proposal for La Serre d'Issy in Paris [39], Benthem Crouwel and Felixx with Valley in Prague [40] or OMA with the Bajes Kwartier in Amsterdam [41] strive for progressive solutions integrating green spaces in architecture to respond to current challenges in cities.

The planning and development of urban regions today faces complex challenges. The functional separation of urban functions, such as working and living, with the aim of reducing density in cities led to a crisis of both resource consumption and the environment [42]. On the other hand, open spaces are much needed in cities, e.g., to mitigate climate change with often rising temperatures and more heavy rain events [43-46]. At the same time, green spaces are understood to have a positive impact on people's well-being and health [47-49].

In order to address the challenges of sustainable development, a detailed assessment and evaluation of density is necessary to allow evidence-based arguments, planning and decision-making. The evaluation of accessible green spaces in the proximity of housing and offices is mostly based on vague data and often considers urban areas as uniform entities, with all the inaccuracies that this implies. We want to present a differentiated view on density, arguing that density can be organized in different ways and by doing so we can achieve very different qualities. For this purpose, we use geospatial data analysis and an in-depth comparative neighborhood study to compare two different cities with different planning approaches, history and culture in Europe and Asia, to reveal different ways of organizing density in the built environment. In a novel approach, we apply a multiscale analysis using different density measurements, correlations between density and green space, as well as the influence of architectural form and spatial structures to understand the accessibility of recreational green on the micro-scale of a building block. This comprehensive approach to understanding density offers a new understanding of green space provision on the daily life neighborhood scale, where previous research is conducted at too large a scale to allow for a nuanced distinction.

The objectives of this study are: (a) to develop a multi-scale analysis method for quantifying and assessing green infrastructures from settlement unit to building level; (b) to identify how density in correlation to green infrastructures can be newly defined to overcome the assumed dichotomy of built vs. unbuilt; (c) to identify if there is an inevitable "correlation" between building and green space density in order to identify a derivation of possible approaches for sustainable development in dense urban regions.

\section{Case Studies: Berlin and Qingdao}

Berlin and Qingdao have been chosen as case studies due to their similarity in population figures as well as the differing approaches they have taken in sculpting their built environment. Both cities developed in an archipelago-logic with districts of varying building and population density interspersed with open and green spaces of different size and qualities. Berlin has 4.6 million inhabitants and Qingdao has 3.8 million [50]. Both cities have given themselves sustainability policies that also address how to develop and manage open spaces [51-53]. With these two study regions we can analyze and critique differing approaches of developing the built environment and assess how these approaches deal with different densities, whether it be building, green, or population density.

Berlin, located in the Northeast of Germany, is a federal city-state and the capital of Germany. It is surrounded by the federal country of Brandenburg as Berlin's rural hinterland. Berlin is the largest city in Germany by population and area. Due to its size and historical characteristics, Berlin offers a broad spectrum of social milieus and types of open spaces and urban configurations [54]. The foundation of Berlin can be dated back to 1170 . On the banks of the Spree River, a twin city developed, formed by Alt-Berlin and Cölln that continuously grew. In the 18th century Berlin became the Royal seat of Prussia and the city was continuously extended, starting with the baroque Friedrichstadt. At the end of the 19th century, in the course of industrialization, there was an immense increase in population and accompanying urban growth with 1.9 million inhabitants around 1900. Development pressure led to the growth of settlement units on the outskirts, which were added to the urban area in 1920 as part of the establishment of Greater Berlin, with a total population 
of 3.8 million inhabitants. Subsequently, these areas were densified by larger settlement projects. In 1942, Berlin had 4.48 million inhabitants, which represents until today the population peak. Due to the impacts of World War II, the German division in 1949, and the division of the city by the Wall in 1961, the population had dropped to 3.04 million by 1978 . The division of Berlin after World War II was particularly formative for the further spatial development of both parts of the city with further inner-city rebuilding and densification in the Western part of the city, and the development of comparatively more new urban quarters in the Eastern part [15].

The urban planning strategy after the reunification in 1989/90 saw the focus on redeveloping the inner city by physically reuniting both parts. Later, the city's expansion into its outskirts and hinterland was promoted in strategic plans, despite the continued population shrinkage [19]. Since 2011, Berlin is facing a relatively high population growth unseen in the city for almost a century [15,55,56]. Therefore, in 2014 the city of Berlin defined its urban development concept by focusing eight strategies around economic strength, quality of life and social conscience. The Berlin Strategy [51] has been constantly updated with the current version being Berlin Strategy 3.0 [52], in which it defines the goal of becoming a climate-neutral metropolis by 2050.

Qingdao is a sub-provincial city in the province of Shandong located on the eastern coast of northern China, approximately $670 \mathrm{~km}$ southeast of Beijing. The period from 1897 to 1949 was the period when the city of Qingdao was formed. During this period, urban planning played an important role in the development direction of Qingdao's urban space. Urban planning at this stage mainly focused on residential areas, but lacked planning and thinking about urban green space. From the 1950s to the 1980s, as a coastal industrial and port city, Qingdao vigorously developed industry, the urban spatial pattern expanded northward, and the urban population grew more rapidly than the green space development [57]. Currently, the sub-provincial municipality Qingdao has a population of 10.1 million inhabitants [58]. Today, major growth occurs along the north and western sides of Jiaozhou Bay $[59,60]$. The urban fabric has been constantly transforming, gradually increasing the density in main urban areas such as the Shibei and Shinan districts. Qingdao is starting a new phase of urban development, brought on by the national government's focus on qualitative urban development. In the National New Urbanization Plan (2014-2020) [61] one of five key areas for qualitative urban development is the building of "green and cultural cities". At present, under the guidance of the "14th Five-Year" Forestry Development Plan of Qingdao City, Qingdao is vigorously promoting the construction of the park green space, including promoting the construction of suburban park green space and the construction of waterfront green space [62]. Following the decades of fast urbanization of China, the national government is shifting its focus to include quality of life in cities in its continued development. As a result of this, in 2016 the Urban Work Conference created a new set of guidelines for the creation of more livable, green, and sustainable cities. The City of Qingdao itself has defined more than 300 sustainability targets in different plans (e.g., Qingdao Masterplan), and policies (e.g., building codes) [53,63-67]. Following national plans, it aims to reach carbon neutrality by $2060[68,69]$.

\section{Materials}

In this study, data-based methods of geospatial analysis are applied, utilizing ArcGIS Pro 2.8.0 [70] using geospatial data from ALKIS Germany [71,72], ESRI World Topographic Map [73], OpenStreetMap [74], ESRI World Imagery [75], Sentinel multispectral satellite imagery [76,77] as well as WorldPop Population Counts [78] and building related information derived from Baidu [79] and Google Maps [80].

\section{Methods}

The analysis is carried out in four steps. In step 1 the study regions for the urban regions of Berlin [81,82] and Qingdao ([83]; excl. Pingdu and Laixi) are defined applying the TOPOI-method [84]. This is a method for identifying settlement units and assessing 
their properties and interconnectivity in a regional setting employing standard planning parameters, such as building density, open space ratio and public transport connectivity, while not regarding administrative boundaries or limits. This comes with the advantage of being highly replicable as a method in different contexts. In step 2, key data is generated by: (i) processing multispectral satellite images that are freely accessible and available in equal quality for the entire globe to identify vegetation; and (ii) calculating the building proximity score based on building footprints to identify clusters of building types. The data and additional information are superposed to the defined study regions and a 100 by $100 \mathrm{~m}$ analytical grid in step 3 . In step 4, the data is analysed in a two-scale assessment framework.

\subsection{Identification of Settlement Units and Definition of Core Urban Area (CUA) with Contiguous} Built-Up Areas as Study Region Applying the TOPOI-Method

The TOPOI method we employ departs from the building footprint to identify the characteristics of different settlement units within regions. Montero et al. [85] identified the four categories as: (1) density measures; (2) classification of remote sensing images; (3) clustering methods grouping elements based on their proximity; and (4) analyses of a statistical distribution for the delineation of cities. To allow an in-depth analysis of the provision of green spaces from the daily life building and neighborhood scale all to the region the TOPOI method describes settlement patterns based on actual qualities and relationships of built-up areas. This is in contrast to conventional planning and analysis methods, which are often based on defining or prescribing certain physical qualities within historically delineated areas, such as districts, zones or administrative units. For the purpose of understanding the micro scale of everyday life, it is crucial to begin at a building scale (see category 3 Montero et al. [85]). Chaudhry et al. [86] developed a method that is based on building footprints yet focuses on identifying the boundaries of urban settlements, i.e., cities and therefore includes settlement units of different characteristics. The settlement units defined by the TOPOI method derive from standard planning parameters to identify and classify built-up areas along the urban and rural areas differing in type and size. A TOPOI settlement unit is defined based on two parameters: a) the maximum distance between buildings, describing the cohesiveness of a built-up group of buildings; and $b$ ) the minimum number of buildings to form such a cohesively built-up settlement unit [84]. The maximum distance of $80 \mathrm{~m}$ between buildings and a minimum building count of eight is used to define cohesively built-up settlement units, including their open spaces, such as green courtyards, smaller and larger squares, etc., while still allowing large infrastructures such as open landscape or multi-lane rail stations to retain their natural barriers [85]. For this study we applied steps 1-2 of the TOPOImethod to the urban regions of Berlin and Qingdao in order to define our comparable study regions. The urban region (A) Berlin is approx. $5550 \mathrm{~km}^{2}$ in size with a population of $4,625,504$ inhabitants and has 2814 settlement units, while (B) Qingdao is $5694 \mathrm{~km}^{2}$ in size with a population of 3,866,844 inhabitants and has 3273 settlement units (see Figure 1).

In the next step, the Natural Breaks (Jenks) algorithm [87] was applied in ArcGIS Pro [70] to determine the threshold that separates large settlement units including the urban core of both regions within the overall network from settlement units of different sizes. The threshold, at which the two groupings of settlement units separate, is 25,404 ha for the urban region of Berlin and 4719 ha for the urban region Qingdao (see Figure 2). The study regions are defined by the core city and directly adjoining settlement units (see Figure 3). 

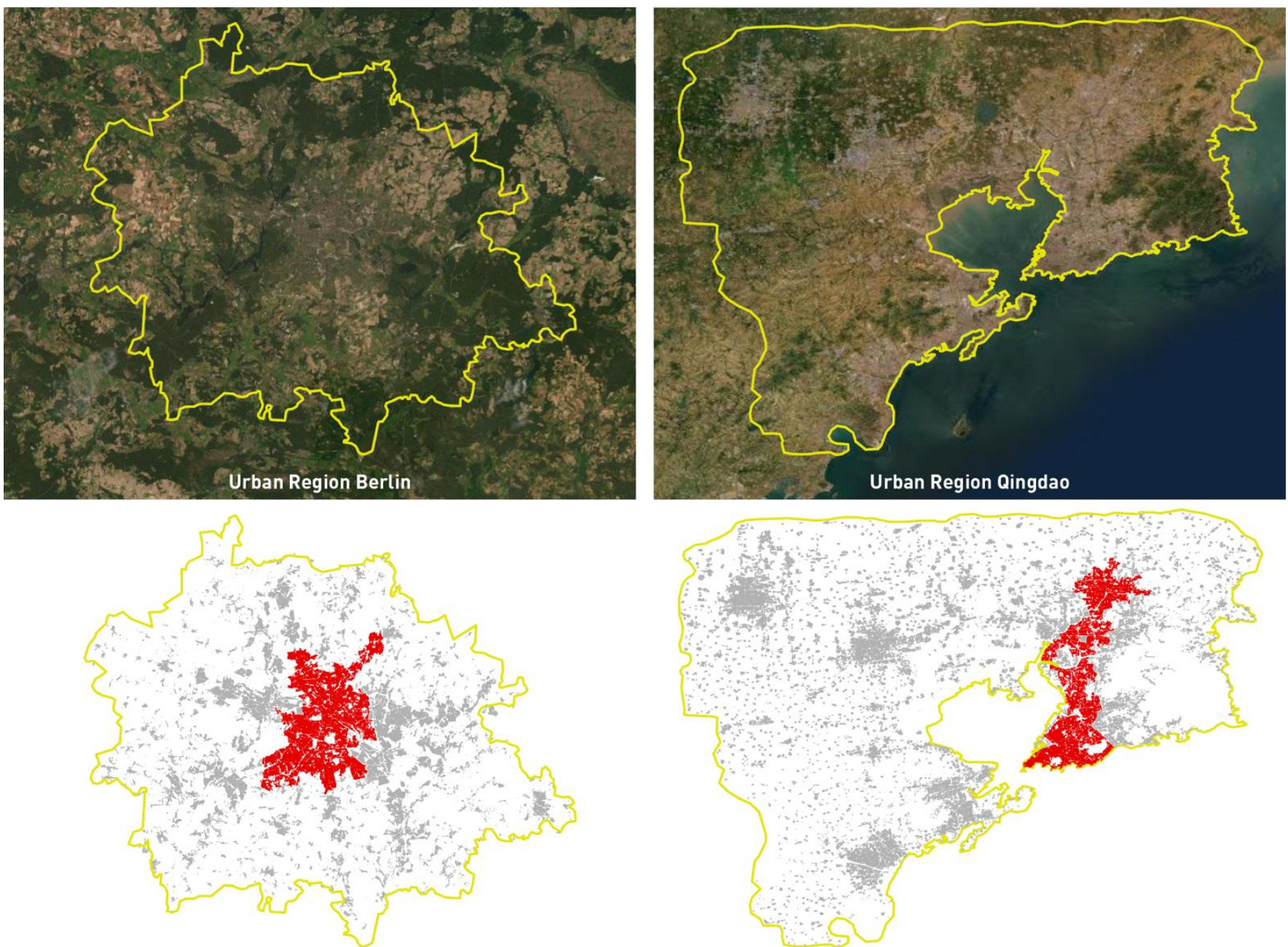

Study Region A (Berlin)

Study Region B (Qingdao)

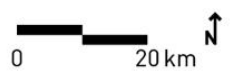

metropolitan region $\square$ study region $\square$ settlement units

Figure 1. To determine the urban core areas of both cities, all settlement units within the respective metropolitan region were identified; Data Sources: [71-75,88]; own calculation.
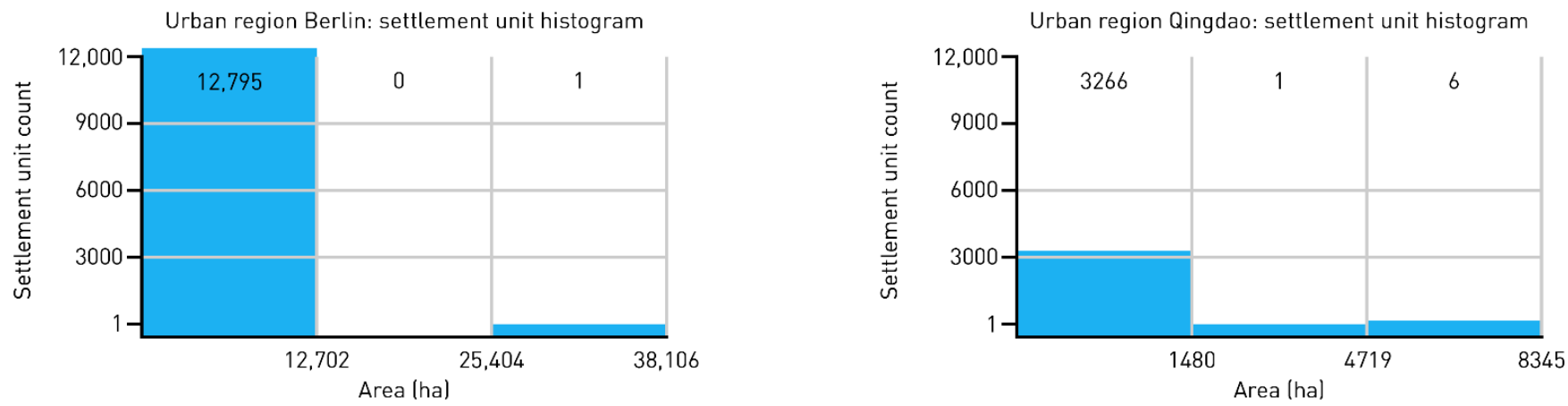

Figure 2. The histogram shows the distribution of settlement units by area. The threshold for the three groups is defined by the Natural Breaks (Jenks) algorithm. Overall, the settlement units in the Berlin urban region are much larger than in Qingdao urban region. The urban core of Berlin is one large continuous settlement unit. The division of the urban core area in Qingdao into four settlement units is a result of the rivers in the urban fabric; the other two settlement units are not connected to the core and lay on the west-side of the bay. 


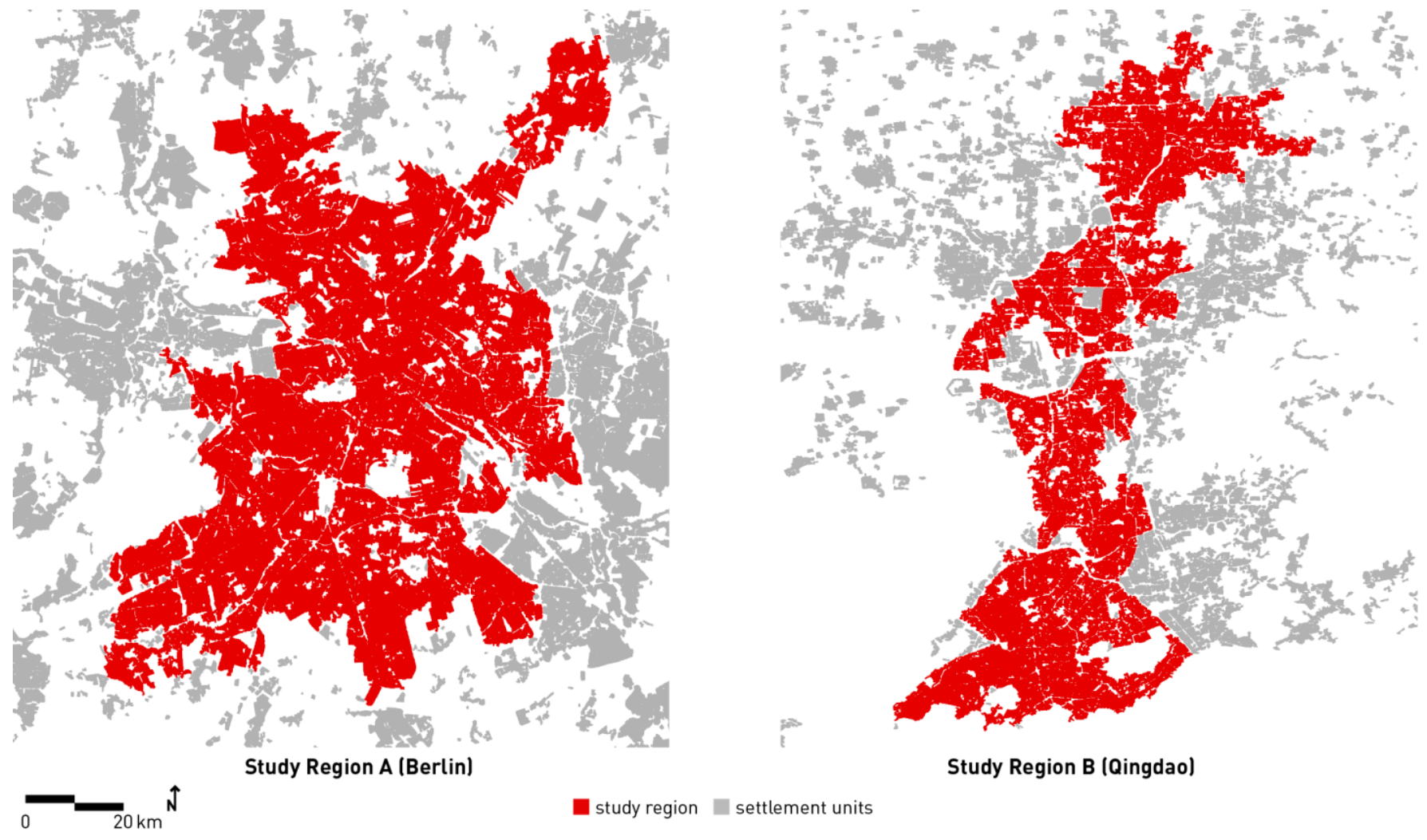

Figure 3. The study area for each urban region is defined by the core urban areas: (A) Berlin with an area of 42,162.49 ha comprising of one large central settlement unit; and (B) Qingdao with an area of 24,806.45 ha comprising of four neighboring large settlement units as most central areas of their region; Data Sources: [71-75,88]; own calculation.

\subsection{Generating Key Data}

This study integrates three different dimensions of density: population, building and vegetation density. The combination of building footprints and vegetation additionally enables the quantification of other sealed surfaces, such as streets and paved areas. While the population figures are obtained from the WorldPop Open Population Repository [89], we apply remote sensing and geospatial analytics methods to generate the information on building density and vegetation.

\subsubsection{Identification of Vegetation Processing Multispectral Satellite Imagery}

To identify and isolate vegetated areas the Normalized Difference Vegetation Index (NDVI) [90] has been applied to Copernicus Sentinel multispectral satellite imagery dating from December 2020 and January 2021 [76,77] to isolate vegetated areas. NDVI identifies surface characteristics based on the absorption and reflection of the Red and Near InfraRed (NIR) spectrum. Healthy vegetation absorbs red light and reflects huge amounts of NIR spectrum due to the process of photosynthesis, and we use this unique signature to identify vegetated areas. NDVI results span in the numeric range from -1 to 1 , where higher values mean higher occurrence of the mentioned signature. Depending on how high the value is set, is the accuracy of the results. A low value may show false positives, however allows the overall quantification of the vegetation, whereas a high value reduces the proportion of identified pixels, yet allows the analysis of characteristic patterns of connected green spaces. In Berlin the band has a minimum of -0.745 and maximum of 1 , in Qingdao it ranges from -0.578 to 0.907 . For the overall quantification of vegetation, we used 0.4 as the minimum threshold for identification (see Figure 4). For the detailed analysis we set the minimum threshold to 0.2 (see Figure 5). The bitmap output is vectorized and imported into a central geodatabase. 


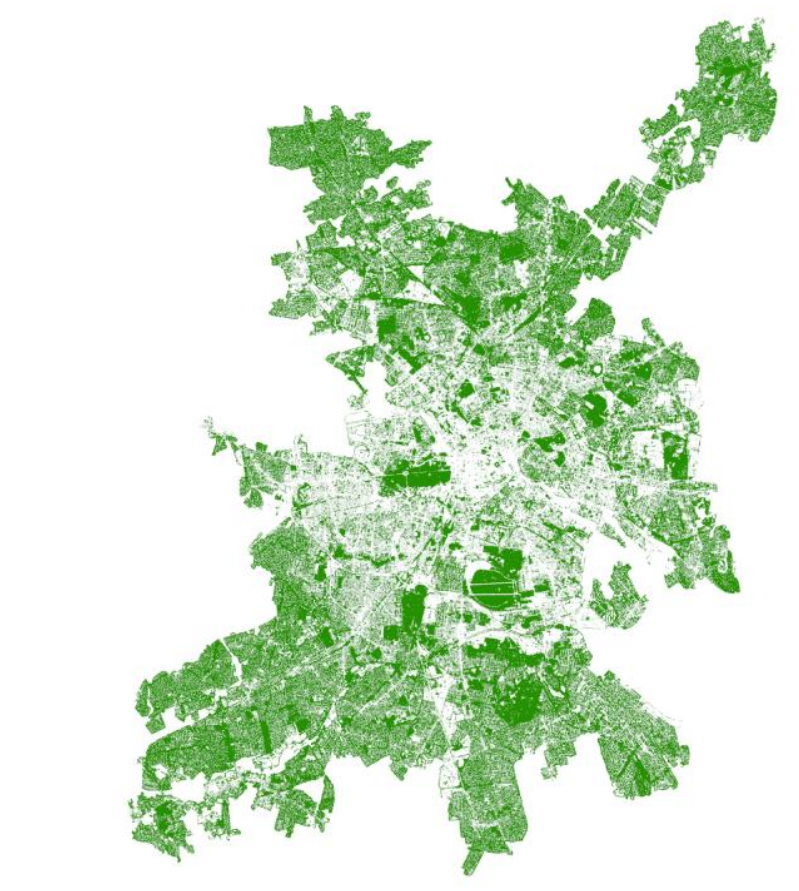

$\prod_{0} \mathrm{~km}^{\uparrow}$
Study Region A (Berlin)

$$
\begin{aligned}
& \text { Vegetation identified by by NDVI } \\
& \text { (Bandwith Threshold } 0.4 \text { ) }
\end{aligned}
$$

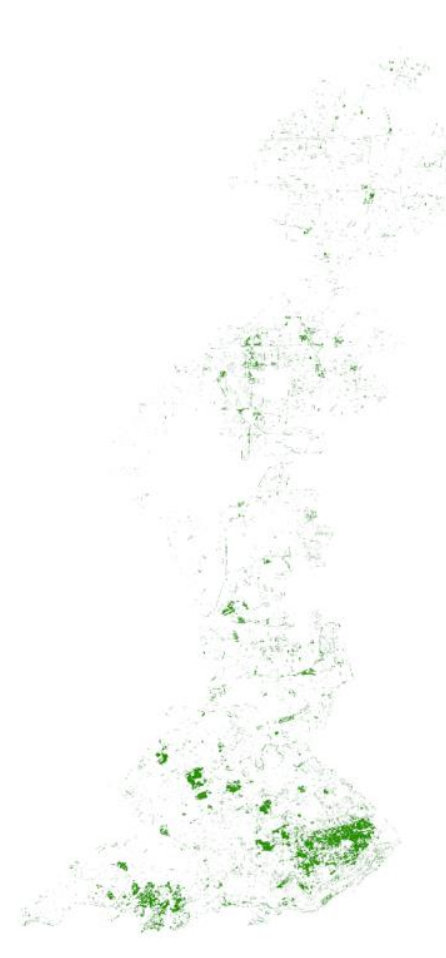

Study Region B (Qingdao)

Figure 4. Identified vegetation applying NDVI analysis with a bandwidth threshold of 0.4; Data Sources: $[76,77,88]$; own calculation.

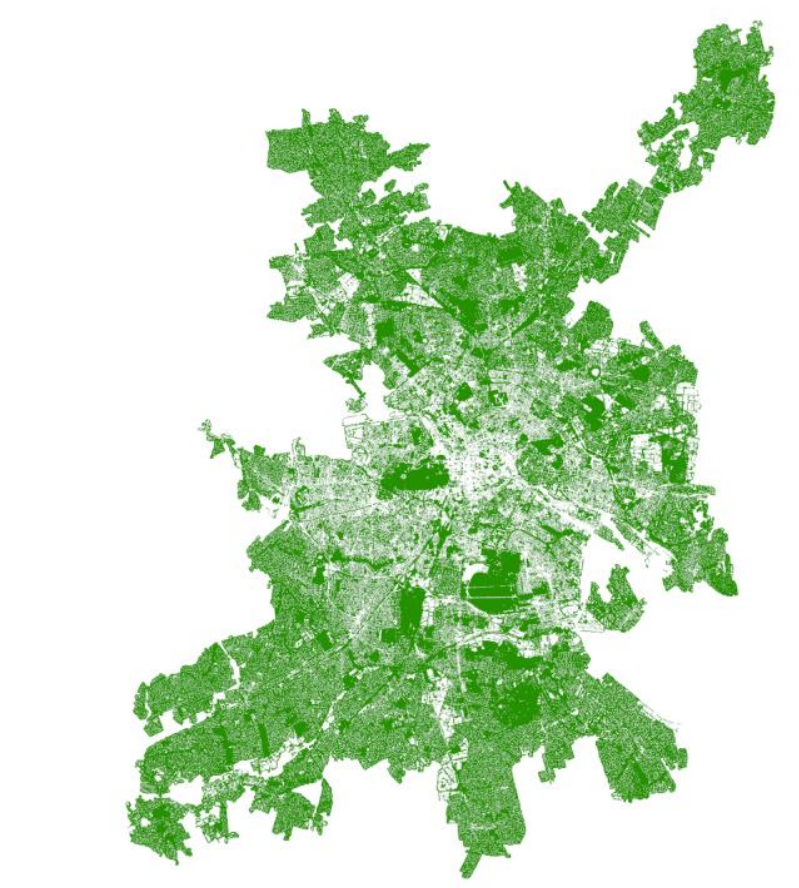

Study Region A (Berlin)

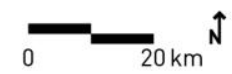

Vegetation identified by by NDVI (Bandwith Threshold 0.2)

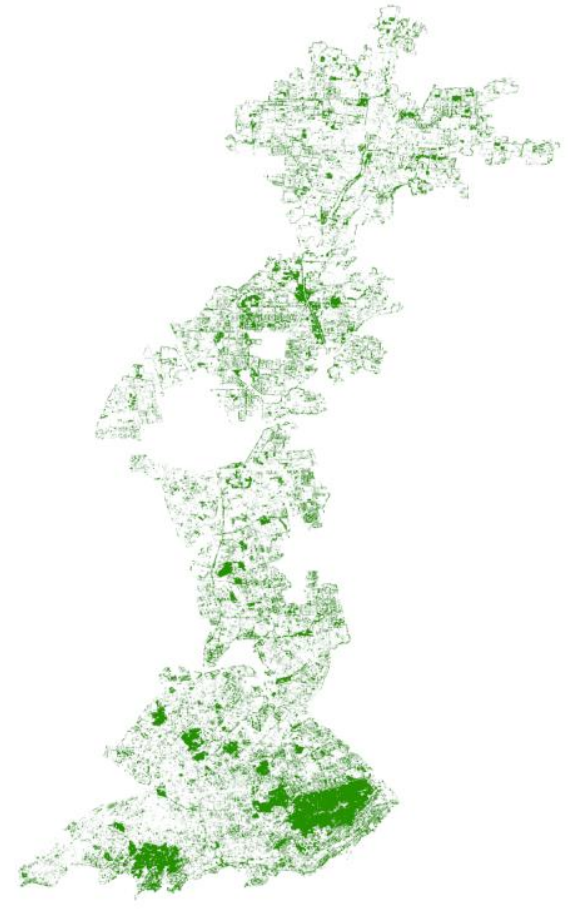

Study Region B (Qingdao)

Figure 5. Identified vegetation applying NDVI analysis with a bandwidth threshold of 0.2; Data Sources: $[76,77,88]$; own calculation. 


\subsubsection{Calculation of Building Proximity Score (BPS)}

A Building Proximity Score (BPS), which we developed for this study, calculates individually for each building the number of buildings within $100 \mathrm{~m}$. The distance was tested at a series of distances from 100 to $450 \mathrm{~m}$, initially with the idea that using $450 \mathrm{~m}$, as it is commonly understood to be the distance of a 5-minute walk, would be the most appropriate. However, $100 \mathrm{~m}$ was found to provide the most precise spatial description of the urban system in high-density urban areas. Once the building density is calculated the buildings are classified using the Natural Breaks (Jenks) methodology. For this classification, the buildings were sorted into 10 proximity classes, from low ( $0-21$ buildings) to high density (194-428) (see Figures 6 and 7).

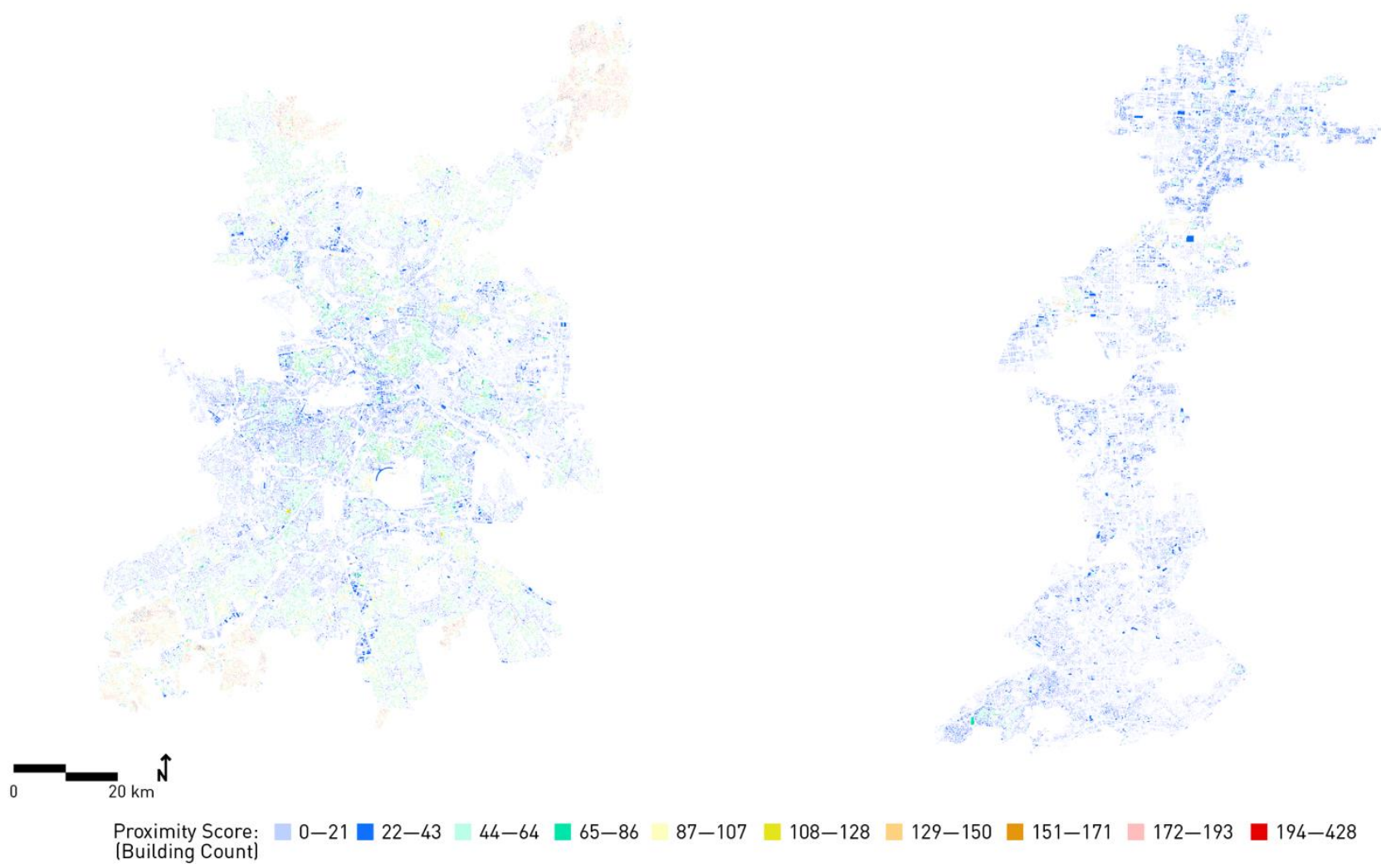

Figure 6. Spatial depiction of the determined classes of the Building Proximity Score; Data Sources: [71-75,88]; own calculation.

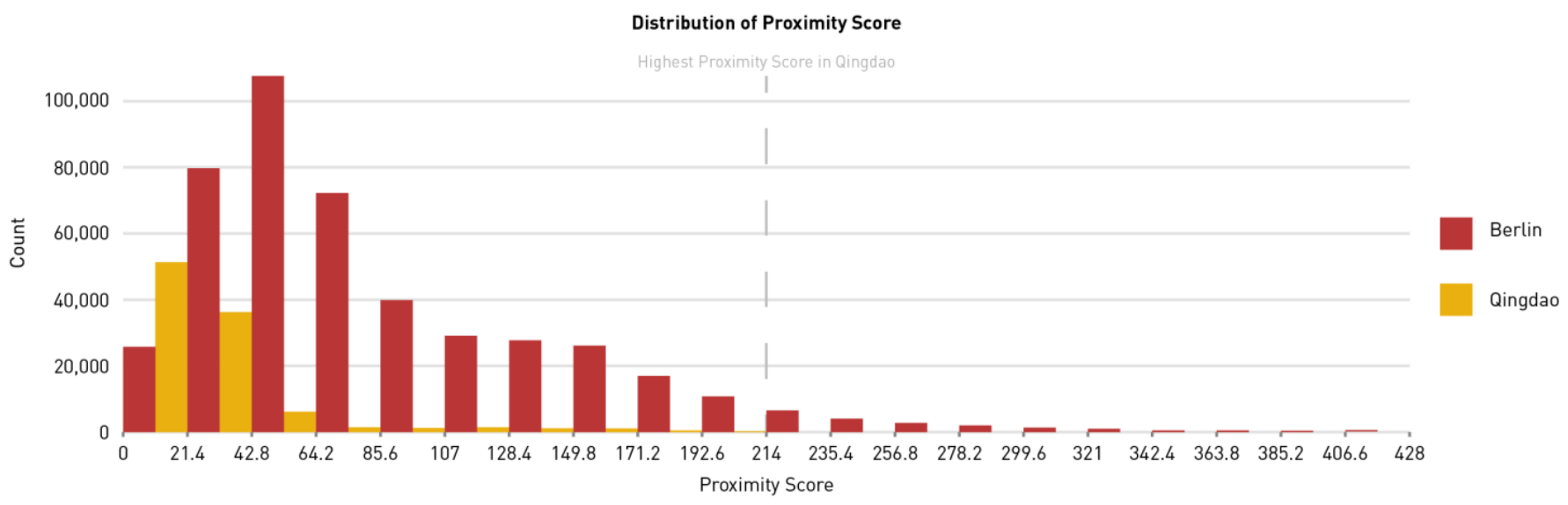

Figure 7. Distribution of the determined classes of the Building Proximity Score. 
Analyzing the distribution of the BPS we see that the range for Qingdao's study region is from 0-215 and the range for Berlin's study region is from 0-428 (see Figure 7). In order to create a set for greater comparison between both study regions we adjust the ranges of the proximity classes: Class I: 0-21, Class II: 22-43, Class III: 4-64, Class IV: 65-171, and Class V: 172-428. Adjusting in this way keeps Qingdao classes, which have over 2000 grid cells, the same as previously, while unifying the tail end of the distribution, which are uneven. Looking into Berlin's Building Proximity numbers we see that the highest levels correspond with the allotment gardens (german: "Kleingärten") on the edges of the urban area. Historically, Kleingärten are gardens with small cabins, which serve self-sufficiency. Today, they offer urbanites access to private green. Due to the small size of the cabins themselves and the plots of land they sit on their proximity scores are very high. This, however, does not cause issues with the resultant distribution of the data, as the purpose of the Building Proximity Score is to identify a cluster of building types and even though it does not take into account the building height, volume, or how buildings are situated in relationship to another, building proximity gives us information about their form.

\subsection{Data Integration}

The previously described data-population [89], buildings proximity score (see Section 4.2.2), vegetation (see Section 4.2.1) —are integrated into a joint geodatabase [88] for the subsequent comparative analysis. Additional attributes such as sealed surface area has been calculated and added. Based on the population dataset, a uniform grid of 100 by $100 \mathrm{~m}$ was created and all available information merged.

\subsection{Evaluation Framework}

The integrated geodatabase allows us to conduct a comparable evaluation of both study regions in two scales: (i) the study region as whole; and (ii) in-depth analysis of six selected neighborhoods identified based on an integrated GIS analysis.

First, we quantify and discuss the population figures, land cover including green spaces and building density for the entire study regions. For better understanding, these are intersected in the following density and spatial distribution analysis to derive two different perspectives on vegetation in the built environment spatially at the grid level: (i) amount of vegetation per person; and (ii) available green space in relation to the building proximity score. Lastly, we identify three neighbourhoods of the same BPS in each study region and enriching the spatial model with information such as building height and inhabitants per building for a detailed analysis of the green structures in relation to the spatial configuration.

\section{Results}

\subsection{Initial Comparison of Both Study Regions}

The study regions of the selected case studies have a population of 2.2 million inhabitants on a total area of 42.1 ha in Berlin and 2.8 million inhabitants on a total area of 28.3 ha in Qingdao (see Table 1). This yields a population density of $8630 \mathrm{Inh} . / \mathrm{km}^{2}$ in Qingdao's study region, which is 1.7 times higher than in Berlin's study region with $5140 \mathrm{Inh} . / \mathrm{km}^{2}$. The distribution of the spatial usage is very different: while the total building footprint is very similar in Berlin's study region at 19.7\% and in Qingdao's study region at 18.1\%, the proportion of vegetation and resulting other sealed area is very different. In the study region of Berlin, $74.1 \%$ of the surfaces are covered with vegetation and only $6.2 \%$ are otherwise sealed; in the study region of Qingdao, the proportion of sealed surfaces is eight times higher at $50.2 \%$ and $31.7 \%$ are vegetated surfaces. This leads to the assumption that Berlin offers a much higher and overall better accessibility to green spaces than Qingdao due to its lower density and higher proportion of vegetated areas. 
Table 1. Data at the level of the entire study regions describing population density, land cover, and quantitative as well as spatial distribution of identified BPS classes.

\begin{tabular}{|c|c|c|c|c|}
\hline & \multicolumn{2}{|c|}{ Study Region Berlin } & \multicolumn{2}{|c|}{ Study Region Qingdao } \\
\hline $\begin{array}{l}\text { Settlement units in } \\
\text { study region }\end{array}$ & 1 & - & 4 & - \\
\hline \multicolumn{5}{|l|}{ Population } \\
\hline Inhabitants total (Inh.) & $2,164,198$ & - & $2,796,692$ & - \\
\hline Mean population density & $5140 \mathrm{Inh} . / \mathrm{km}^{2}$ & - & 8630 Inh. $/ \mathrm{km}^{2}$ & - \\
\hline $\begin{array}{l}\text { Mean population per grid cell } \\
(100 \text { by } 100 \mathrm{~m})\end{array}$ & 27.0 Inh. & - & 78.7 Inh. & - \\
\hline \multicolumn{5}{|l|}{ Land cover } \\
\hline Area Total (ha) & $42,126.5$ ha & & $28,306.6$ ha & \\
\hline Building footprint area & $8291.4 \mathrm{ha}$ & $19.7 \%$ & $5113.4 h a$ & $18.1 \%$ \\
\hline Vegetation area (NDVI 0.2) & $31,212.8 \mathrm{ha}$ & $74.1 \%$ & 8969.9 ha & $31.7 \%$ \\
\hline Sealed land & $2622.3 \mathrm{ha}$ & $6.2 \%$ & $14,223.3 \mathrm{ha}$ & $50.2 \%$ \\
\hline $\begin{array}{l}\text { Mean area "vegetation" per } \\
\text { cell (NDVI 0.2) }\end{array}$ & 0.37 ha & - & 0.12 ha & - \\
\hline $\begin{array}{l}\text { Building Proximity Score } \\
\text { (BPS) Class }\end{array}$ & $\begin{array}{l}\text { Building } \\
\text { count }\end{array}$ & $\begin{array}{l}\text { Cells } \\
\text { covered [\%] }\end{array}$ & $\begin{array}{l}\text { Building } \\
\text { count }\end{array}$ & $\begin{array}{c}\text { Cells } \\
\text { covered [\%] }\end{array}$ \\
\hline BPS Class I & 14,975 & $23 \%$ & 32,365 & $47 \%$ \\
\hline BPS Class II & 61,669 & $25 \%$ & 54,502 & $44 \%$ \\
\hline BPS Class III & 106,460 & $23 \%$ & 14,628 & $7 \%$ \\
\hline BPS Class IV & 229,719 & $26 \%$ & 8832 & $2 \%$ \\
\hline BPS Class V & 74,558 & $3 \%$ & 2089 & $0.0016 \%$ \\
\hline
\end{tabular}

For the next steps of assessment, we have therefore taken a closer look at the different classes of the Building Proximity Score. Although the building footprint shows comparable proportions, the characteristics in terms of density are very different. In Qingdao's study region $77 \%$ of the buildings in the region are located in areas with the two lowest proximity classes and this is contrasted in Berlin's study region where the third and fourth highest levels of proximity classes are where $69 \%$ of buildings are located. From this we can deduct that the dominant urban planning patterns differ greatly between the two sites. Berlin's study region being primarily composed of perimeter blocks, row or slab buildings and Qingdao's study region being primarily comprised of "superblocks" with mid to high rise buildings.

This leads us to the question of whether it is possible to identify differentiated patterns of the relationship between vegetation and population density, as well as building density across the entire study regions.

\subsection{Vegetation Density and Spatial Distribution Analysis}

\subsubsection{Intersecting Vegetation Data with Population Figures}

At this stage, we analyze the ratio of vegetated area to the population figures in a more precise resolution, for which the unified 100 by $100 \mathrm{~m}$ grid is used. Each grid cell contains the information for the population and how much area is made up of green. This allows us to calculate the ratio of vegetation per person within each grid cell (see Figure 8). Berlin's study region including large park areas and nature reserves averages around $3700 \mathrm{~m}^{2}$ of vegetation per person in its central areas with Qingdao's study region being twice as lower with $1200 \mathrm{~m}^{2}$ of vegetation per person. The areas of Berlin with the highest amount of vegetation per person are the allotment garden areas, which are small cabins surrounded by garden space and are frequently found in German cities and towns. The main open 
vegetated space of central Qingdao is primarily located in the small mountain area, which borders the east of the study region. It is largely uninhabited and therefore not included in this study.

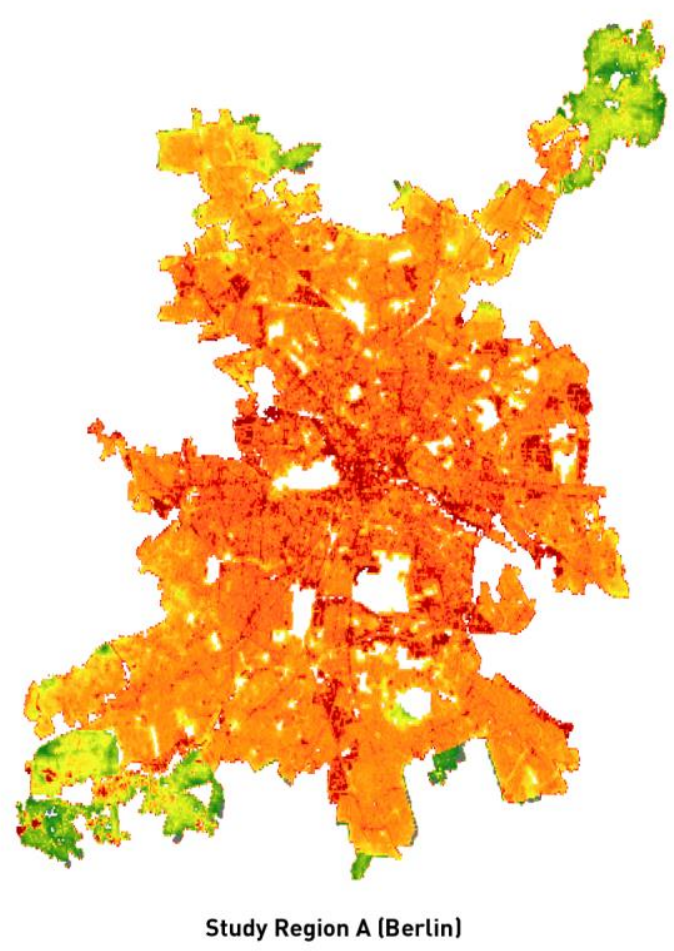

sqm of Green Space per person

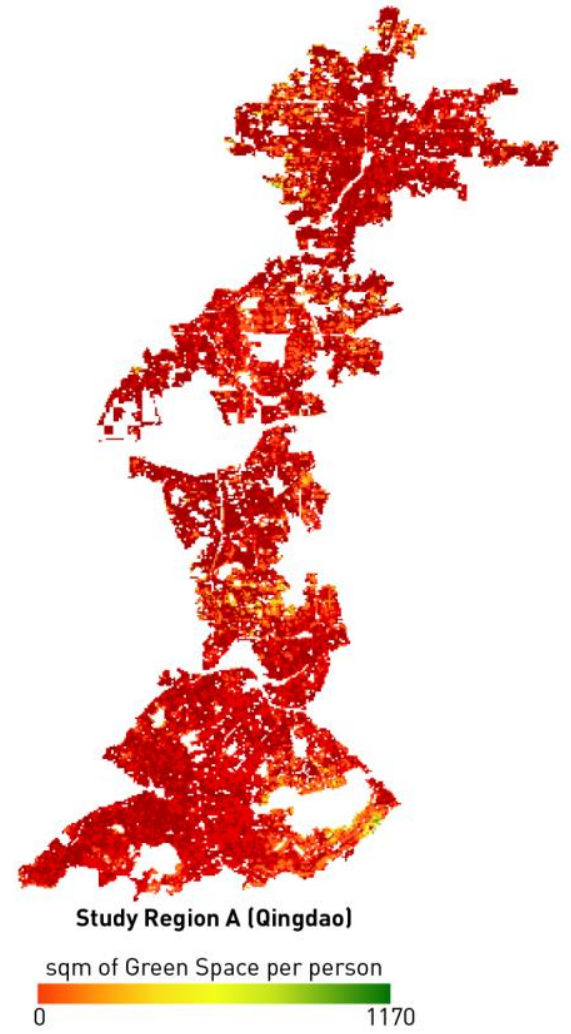

Figure 8. The ratio of vegetation per person shows varying patterns for the study regions: (A) Berlin, which is characterized by homogenized distribution; (B) Qingdao overall has a similar distribution but with lower levels of green space per person. Note: Large green areas such as parks are excluded in this analysis as they do not have any population data; Data Sources: [76,77,88,89]; own calculation.

\subsubsection{Intersecting Vegetation Data with Building Proximity Score (BPS) Classes}

In Figure 9 we see the relationship between the BPS class and vegetation share per grid cell. On the $x$-axis we have the percentage of vegetation per grid cell and on the $y$-axis, we have the count for how many grid cells fall into that percentage. This is split into five separate classes, one for each BPS Class. We can see in the graphs that Berlin' study region has the full range of percentage of vegetation per cell in each BPS Class, which is indicative of a varied pattern of vegetation versus built environment across the city. 

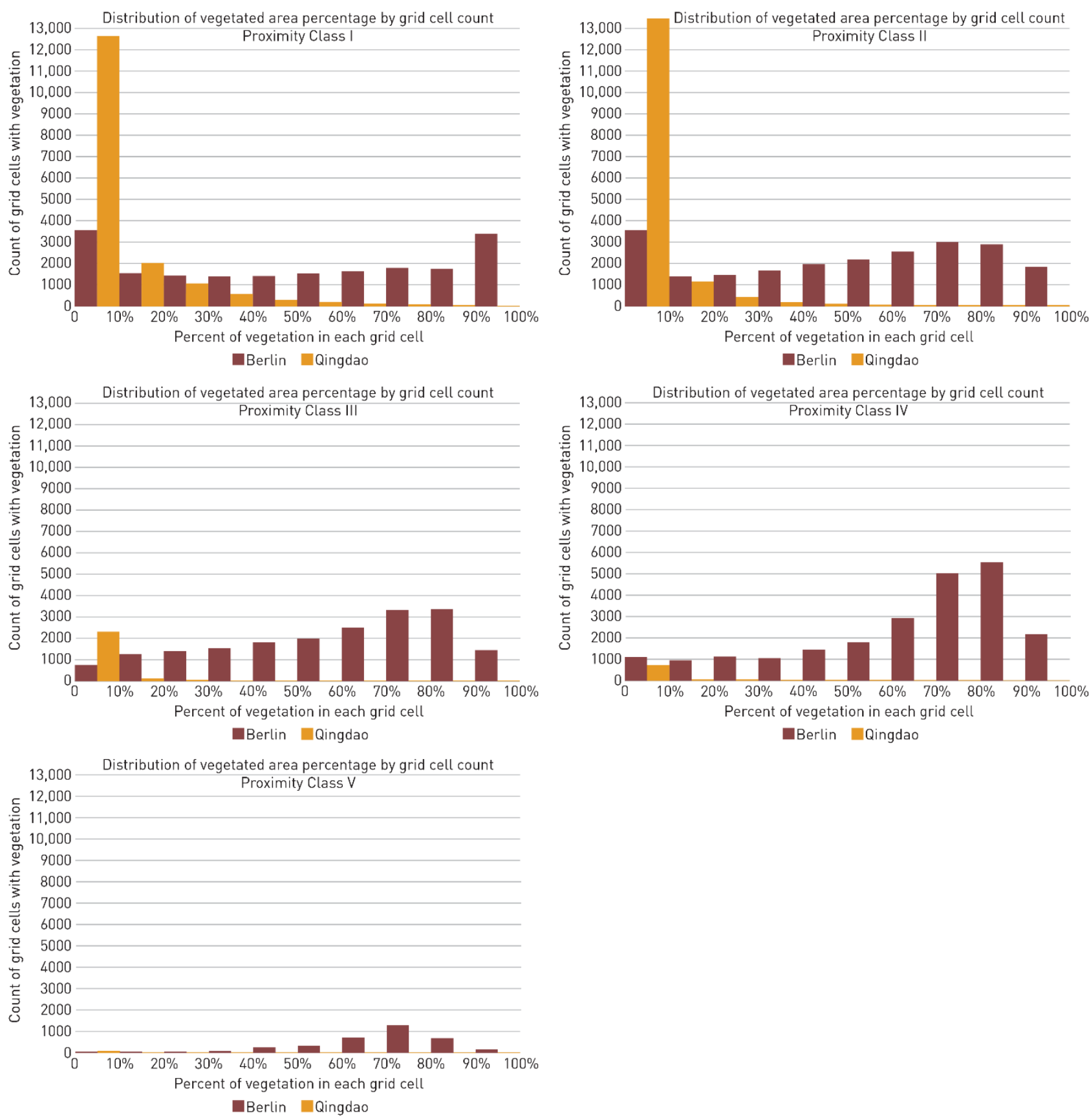

Figure 9. Distribution of vegetated area according to the building proximity score class.

Qingdao's study region, on the other hand, has a uniform distribution at each BPS Class, with the vast majority of its grid cells throughout the city having $0-10 \%$ vegetation. It can be assumed that the low proportion is due to a high building density and the high degree of sealing (see Table 1). For a comprehensive evaluation, this would require a higherresolution database. Since this is not available, we will analyze selected neighborhoods in more depth (see Section 5.3).

\subsection{Neighborhood Based Analysis of Access to Green Spaces in the Built Environment}

For the neighborhood-based analysis the building proximity score was utilized as the starting point to define the sites for analysis. Looking at Figure 9 we can see that the overlap between Berlin and Qingdao, when it comes to building proximity occurs from a BPS of 0-64, i.e., BPS classes I, II, and III. Therefore, we determine three neighborhood 
sites in Berlin (see Figure 10) and three sites in Qingdao (see Figure 11) within grid cells where the mean BPS is within these classes. Data on population, (residential) buildings including footprint, height, gross building volume and gross floor area and land cover of open spaces, i.e., paved and green areas, is aggregated (see Table 2).
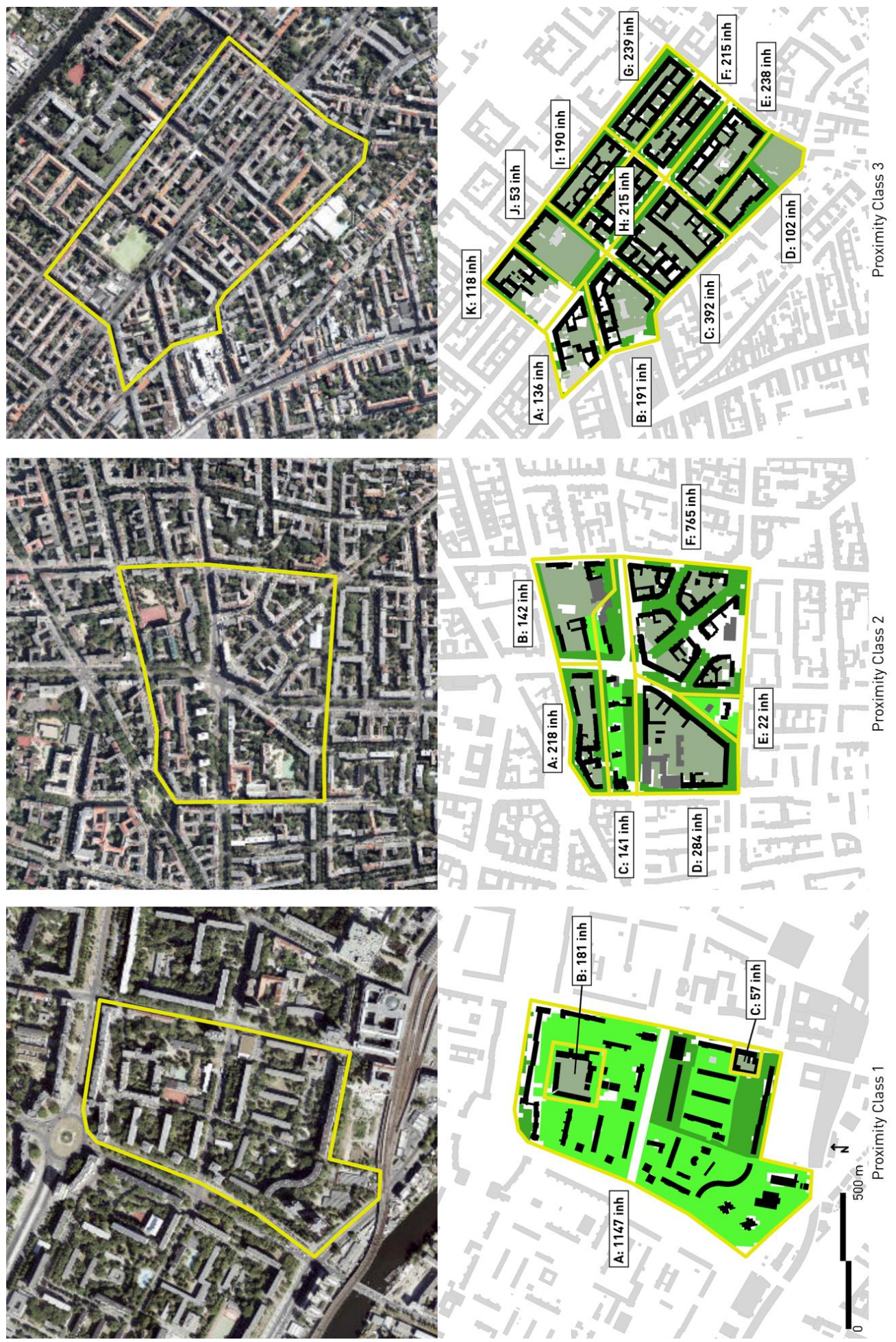

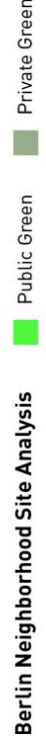

Figure 10. Selected study sites in the core urban area of Berlin. The NDVI identified vegetation is manually qualified into the subcategories: public, private and street green. The boundaries of the residential units (A-K) are manually identified while the numbers of inhabitants are distributed by geospatial analytical methods; Data Sources: [75,88]; own calculation. 

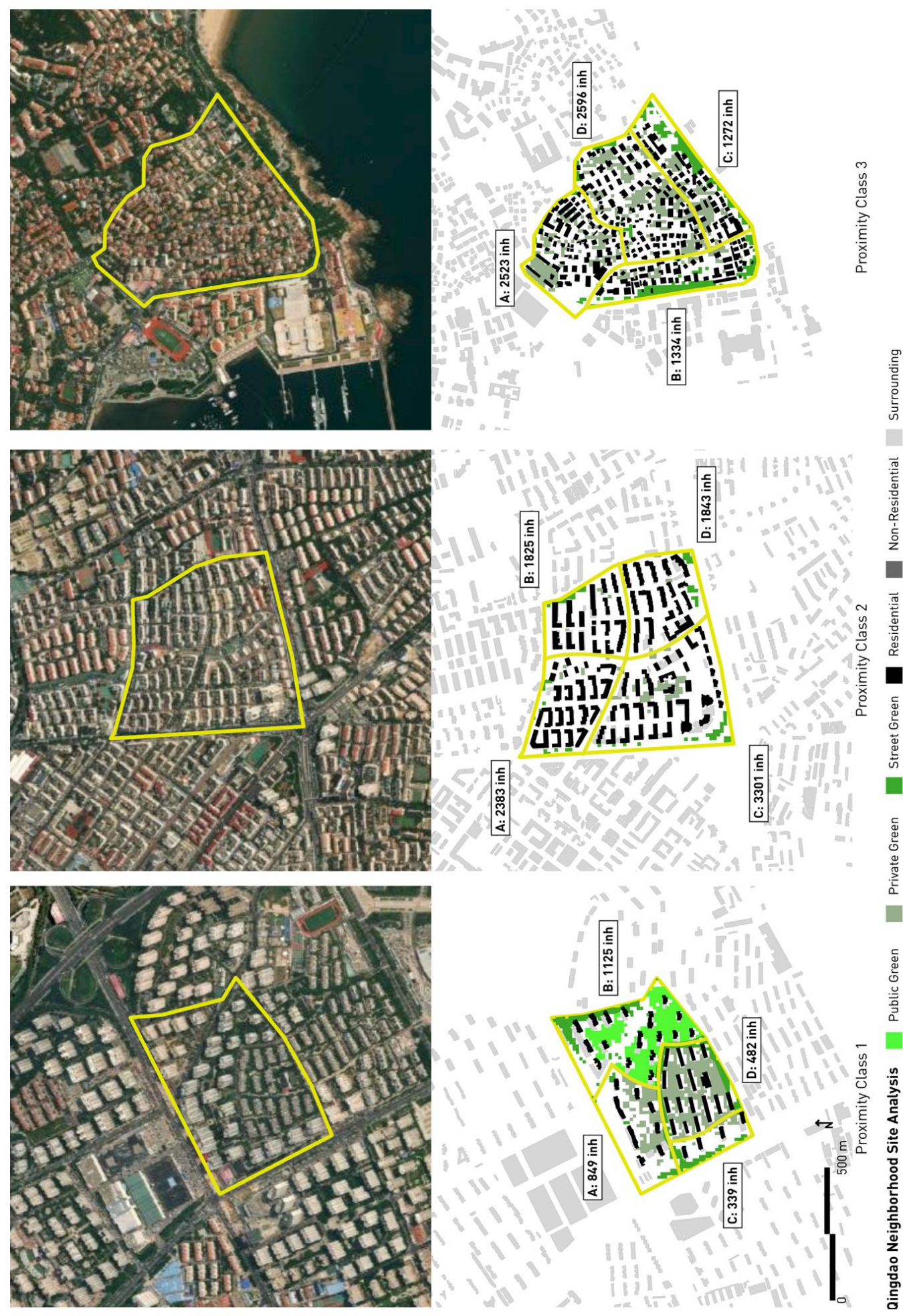

Figure 11. Selected study sites in the core urban area of Qingdao. The NDVI identified vegetation is manually qualified into the subcategories: public, private and street green. The boundaries of the residential units (A-K) are manually identified, while the numbers of inhabitants are distributed by geospatial analytical methods; Data Sources: [75,88]; own calculation. 
Table 2. Data on population, buildings and open spaces for the study sites in the core urban area of Berlin and Qingdao. The selected sites are comparable in size yet differ in parameters such as population density or gross building volume.

\begin{tabular}{|c|c|c|c|c|c|c|c|}
\hline & & \multicolumn{3}{|c|}{ Study Region Berlin } & \multicolumn{3}{|c|}{ Study Region Qingdao } \\
\hline & & BPS I & BPS II & BPS III & BPS I & BPS II & BPS III \\
\hline & Total Area [ha] & 22.8 & 22.0 & 25.7 & 21.4 & 24.5 & 25.6 \\
\hline & Population [Inh.] & 1385 & 1571 & 2089 & 2795 & 9354 & 7725 \\
\hline & Population Density [Inh/ha] & 62.6 & 71.7 & 83.5 & 130.0 & 381.0 & 301.0 \\
\hline \multirow{5}{*}{ BUILDINGS } & Residential Building Count & 39 & 115 & 197 & 46 & 92 & 279 \\
\hline & Total Building Footprint [ha] & 4.1 & 5.3 & 9.0 & 2.9 & 6.8 & 6.2 \\
\hline & Residential Building Footprint [ha] & 3.1 & 4.3 & 8.2 & 2.9 & 6.3 & 6.2 \\
\hline & Gross Building Volume [Million $\mathrm{m}^{3}$ ] & 1.19 & 1.26 & 2.18 & 1.73 & 1.89 & 0.85 \\
\hline & Gross Floor Area $\left[\mathrm{m}^{2}\right]$ & 294,000 & 276,000 & 507,000 & 402,000 & 440,000 & 198,000 \\
\hline \multirow{5}{*}{$\begin{array}{c}\text { OPEN } \\
\text { SPACES }\end{array}$} & Total Paved Area [ha] & 1.4 & 3.2 & 2.9 & 8.6 & 16.3 & 12.4 \\
\hline & Total Green Area [ha] & 17.3 & 13.5 & 13.8 & 10.0 & 1.4 & 7 \\
\hline & Private Green [ha] & 1.1 & 6.1 & 7.7 & 4.0 & 0.7 & 4.6 \\
\hline & Street Green [ha] & 3.1 & 6.2 & 6.1 & 2.7 & 0.7 & 2.4 \\
\hline & Public Green [ha] & 12.9 & 1.2 & - & 3.3 & - & - \\
\hline
\end{tabular}

A further breakdown was required due to the differing qualities of the green spaces. The previous analysis can only tell us if a grid cell includes vegetation, and to what extent it is not related to types of green spaces. Therefore, we broke down the vegetation into three categories: private green, street green, and public green. Private green areas are areas of vegetation only accessible to a subset of the population, such as courtyards or gated communities. Public green areas are areas of green in the neighborhood open and accessible to all. Street green areas are the small pockets of green along streets and serve more as transitional spaces. The latter, although they have a positive impact on, e.g., micro climate and visual experiences in cities, are excluded from our analysis focusing on recreational activities that streets can only fulfill to a certain degree and not for all population groups, since they often do not permit lingering without consumption or play.

As the different green spaces are primarily shaped by the buildings in these two sites, we calculated the inhabitants per building based on their overall volume. To do so the height of the buildings was calculated using Google Maps [80] and Baidu Maps [79]. Next, the height of each building was calculated based on this and then used to calculate the volume. The population numbers were then distributed from the population grid cell to the building based on the share of total building volume within each grid cell.

The last thing to be distinguished is the grouping of buildings based on their relationship to the surrounding green. For all six sites subdivisions were made based on each building's relationship to each other, streets, and green spaces resulting in a subdivision from A to K. Now that the buildings have been grouped and have population figures we can begin to assess the relationship of population to green type, as seen in Tables 3 and 4 and Figure 12. 
Table 3. Study sites Berlin: Accessible recreational green space, which includes public and private green and excluding street green (see definition in Section 5.3), for housing units and their residents.

\begin{tabular}{|c|c|c|c|c|c|c|c|c|c|}
\hline \multicolumn{10}{|c|}{ Study Region Berlin: Accessible Green Areas Per Housing Unit } \\
\hline \multirow{3}{*}{$\begin{array}{l}\text { Housing } \\
\text { Unit }\end{array}$} & \multirow{3}{*}{$\begin{array}{l}\text { Number } \\
\text { of Inh. }\end{array}$} & \multicolumn{2}{|l|}{ BPS I } & \multicolumn{3}{|c|}{ BPS II } & \multicolumn{3}{|c|}{ BPS III } \\
\hline & & \multicolumn{2}{|c|}{$\begin{array}{l}\text { Accessible Green } \\
\text { (private + public) }\end{array}$} & Inh. & \multicolumn{2}{|c|}{$\begin{array}{l}\text { Accessible Green } \\
\text { (private + public) }\end{array}$} & Inh. & \multicolumn{2}{|c|}{$\begin{array}{l}\text { Accessible Green } \\
\text { (private + public) }\end{array}$} \\
\hline & & Total [ha] & {$\left[\mathrm{m}^{2} /\right.$ person] } & & Total [ha] & {$\left[\mathrm{m}^{2} /\right.$ person] } & & Total [ha] & {$\left[\mathrm{m}^{2} /\right.$ person] } \\
\hline A & 1147 & 16.1 & 140 & 218 & 1.8 & 82 & 136 & 0.4 & 29 \\
\hline B & 181 & 17.1 & 944 & 142 & 2.6 & 183 & 191 & 1.1 & 57 \\
\hline $\mathrm{C}$ & 57 & 16.2 & 2842 & 141 & 1.2 & 85 & 392 & 1.3 & 33 \\
\hline $\mathrm{D}$ & - & - & - & 284 & 3 & 105 & 102 & 0.4 & 34 \\
\hline$E$ & - & - & - & 22 & 1.2 & 585 & 238 & 0.8 & 31 \\
\hline $\mathrm{F}$ & - & - & - & 765 & 4.6 & 60 & 215 & 0.4 & 19 \\
\hline G & - & - & - & - & - & - & 239 & 0.5 & 19 \\
\hline $\mathrm{H}$ & - & - & - & - & - & - & 215 & 0.9 & 43 \\
\hline I & - & - & - & - & - & - & 190 & 1.4 & 74 \\
\hline $\mathrm{J}$ & - & - & - & - & - & - & 53 & 0.2 & 33 \\
\hline $\mathrm{K}$ & - & - & - & - & - & - & 118 & 0.5 & 41 \\
\hline
\end{tabular}

Table 4. Study sites Qingdao: Accessible recreational green space, which includes public and private green and excluding street green (see definition in Section 5.3), for housing units and their residents.

\begin{tabular}{|c|c|c|c|c|c|c|c|c|c|}
\hline \multicolumn{10}{|c|}{ Study Region Qingdao: Accessible Green Areas Per Housing Unit } \\
\hline \multirow{3}{*}{$\begin{array}{l}\text { Housing } \\
\text { Unit }\end{array}$} & \multicolumn{3}{|c|}{ BPS I } & \multicolumn{3}{|c|}{ BPS II } & \multicolumn{3}{|c|}{ BPS III } \\
\hline & $\begin{array}{l}\text { Number } \\
\text { of Inh. }\end{array}$ & \multicolumn{2}{|c|}{$\begin{array}{l}\text { Accessible Green } \\
\text { (private + public) }\end{array}$} & $\begin{array}{l}\text { Number } \\
\text { of Inh. }\end{array}$ & \multicolumn{2}{|c|}{$\begin{array}{l}\text { Accessible Green } \\
\text { (private + public) }\end{array}$} & $\begin{array}{l}\text { Number } \\
\text { of Inh. }\end{array}$ & \multicolumn{2}{|c|}{$\begin{array}{l}\text { Accessible Green } \\
\text { (private + public) }\end{array}$} \\
\hline & & Total [ha] & {$\left[\mathrm{m}^{2} /\right.$ person] } & & Total [ha] & {$\left[\mathrm{m}^{2} /\right.$ person] } & & Total [ha] & {$\left[\mathrm{m}^{2} /\right.$ person] } \\
\hline A & 849 & 7.4 & 87 & 2383 & 0.1 & 0.3 & 2523 & 1.2 & 4.7 \\
\hline B & 1125 & 6.7 & 59 & 1825 & 0.1 & 0.3 & 1334 & 0.4 & 0.9 \\
\hline $\mathrm{C}$ & 339 & 6.7 & 197 & 3301 & 0.5 & 1.6 & 1272 & 0.9 & 6.9 \\
\hline $\mathrm{D}$ & 482 & 8.8 & 182 & 1843 & 0.1 & 0.3 & 2596 & 2.1 & 8.0 \\
\hline
\end{tabular}

The study sites with the greatest amount of green accessible to their residents are found in Proximity Class 1 for Berlin and Qingdao. In both of these study sites the building stories are higher than in the other sites, with Berlin's site being comprised of slabs and towers, while Qingdao's site morphology follows the typical Chinese super-block. Each of these utilize mid to high-rise buildings to free as much of the ground as possible for green space, also reducing paved surfaces or buildings. In doing so, these sites are able to provide higher levels of green to more people.

Study sites 2 and 3 in Berlin feature the typical Berlin perimeter block buildings with courtyards, which are often subdivided. While from an aerial perspective the amount of green in these courtyards is more than sufficient for a per person level, in reality when you engage with these spaces they are commonly not of high quality and not frequently used, as they are often cramped and constricted by the form of the buildings, which surround and block sunlight. Additionally, these spaces are private and do not serve the larger community, unlike the green spaces in study sites 1 . 

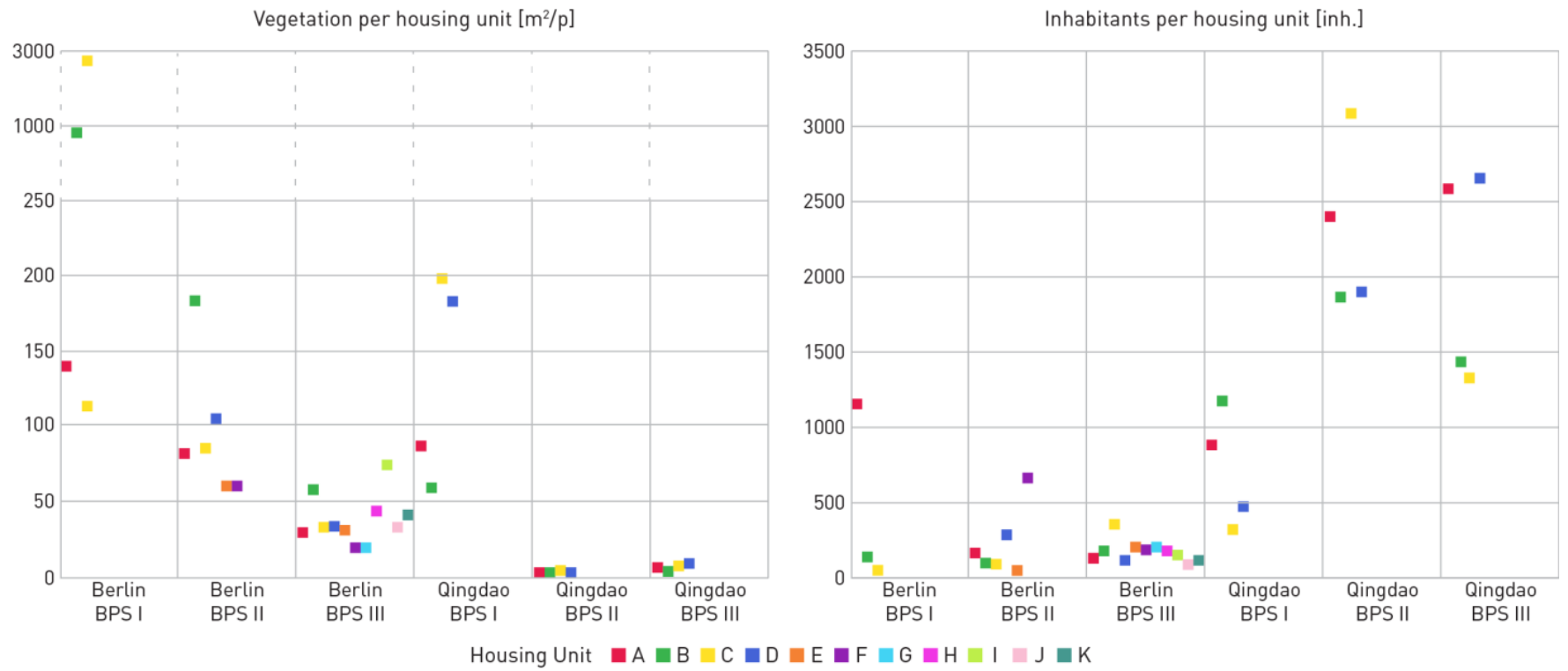

Figure 12. Accessible green space for housing units and their residents and population numbers for the neighborhood sites by building proximity score classes (BPS) in Berlin and Qingdao.

Study site 2 in Qingdao is an example of the housing blocks built in the 1960s in China and consist of $4-5$ story high row buildings spaced tightly together with little to no green space, or most commonly just a few single trees. While these neighborhoods can house a large number of people the quality of life of the spaces between the buildings is frequently poor, as seen in the numbers (see Tables 2 and 4).

Study site 3 in Qingdao is a neighborhood almost entirely consisting of villa style housing from the colonial days of Qingdao. Initially built as single-family homes these houses have been split into multifamily houses. As such the private green spaces that exist, which may have originally been suitable, have been split-up, subdivided, and built on, resulting in low green numbers for the neighborhood. This building type is a bit of an anomaly in China, where very few single-family housing complexes were built.

If we look to see which study sites have similar numbers of green per person, we identify Berlin's BPS II and Qingdao's BPS I. Both sites have housing that is able to reach from 50-190 sqm of green per person. However, they achieve this in quite different ways. The neighborhood in Berlin is dominated by 4-6 story perimeter blocks with 6.1 ha of private green, 6.2 ha of street green, and 1.2 ha of public green. This means that only $11 \%$ of the available green space in the site consists of actually green areas, which are designed for people. The Qingdao site offers 4 ha of private green, 2.7 ha of street green and 3.3 ha of public green for $33 \%$ of publicly accessible green space, while at the same time having a population of 2,795 inhabitants compared to the Berlin site's 1,571 inhabitants. This is due, in large part, to the form of the residential buildings in Qingdao, which are residential high-rise buildings of up to 20 stories. In this case a high population density can be given good numbers for accessibility to green through a smarter building form.

\section{Discussion}

On an aerial level of analysis, we can see that Berlin has an overall larger volume of vegetation than Qingdao. However, as the level of analysis gets smaller focusing on individual neighborhoods in the dense inner-city core, we can begin to see that there is another level of examination to be conducted. In the case of Berlin, the vast majority of blocks within the core urban area have some amount of green, however the accessibility and quality of these green spaces are more often than not poor. This is in large part due to the morphology of the buildings that guide the form of the green spaces. The dominant building form in Berlin's city center is the perimeter block, which results in small green 
spaces that are private. As a result, the green spaces are chopped and sequestered on the ground level while on the aerial level the NDVI is not able to make these distinctions (see Figure 10 and Table 3). In the neighborhood sites in Qingdao we used for closer analysis, we saw single family housing villas from the colonial era, early mid-rise apartment blocks, and the Chinese "super block". Each have very different relationships between building form, population density, and green. Single family housing has entirely private green, mid-rise apartment blocks have little to no green at all, and the "super block" has large, open green areas (see Figure 11 and Table 4).

If we look at Qingdao's neighborhood site in BPS class 1, we can see that the numbers for green $\mathrm{m}^{2} / \mathrm{p}$ fall within ranges similar to that of Berlin's BPS class 2 . While these sites do have differing BPS classes, they are both their respective cities standard form for building new developments moving forward. Therefore, they can serve as an apt comparison. Qingdao's contemporary urban development form achieves similar numbers of green while having a larger number of residents, and of course this makes sense as the buildings consist of high-rise towers of up to 20 stories. A further commitment to this type would greatly change the green levels in Qingdao and this is the plan outlined at the national level by the Chinese government.

As seen from the high population numbers of the sites, the issues of housing are evident in these cities. In Qingdao, this manifests itself in extremely high population densities and in Berlin in rising prices and scarcity. In both of these conditions, along with the issue of access to green areas, a potential solution can be found in the morphology of study site 1 in Berlin and Qingdao. The question of how density and green accessibility can be tackled lies on the level of urban and architectural form. High density of population and green can be addressed through urban planning policy, which places importance on freeing up land surface by utilizing mid and high-rise buildings, and reducing paved areas, while scaling the site to be large enough so that the resultant green space gained by using towers offers enough green space for the residents of its site and neighboring areas.

Future research could bring in an additional layer of analysis to provide insights on the accessibility to recreational spaces related to social inequality. This could be done by examining accessibility as determined by socioeconomic criteria. The COVID-19 pandemic brought to light the fact that the issue of accessibility to recreational green spaces being in close proximity to one's place of residence is crucial, in particular in dense urban areas.

The analysis is based on freely accessible data available for both study regions. Our study could be further detailed and automatized applying data-driven methods such as semantic segmentation or agglomerative clustering, for which very high resolution (VHR) resources as well as 3D data to describe the built environment are required. This would allow the detailed typification of green spaces in the context of the built environment. Based on this, a new assessment standard could be developed to evaluate the availability and accessibility of recreational spaces in high-density urban regions.

Author Contributions: Conceptualization, O.M., R.Z., V.M.C. and N.D.; methodology, O.M., R.Z. and V.M.C.; investigation, R.Z., O.M., V.M.C. and N.D.; writing-original draft preparation, O.M. and R.Z.; writing-review and editing, V.M.C. and N.D.; funding acquisition, V.M.C. and O.M. All authors have read and agreed to the published version of the manuscript.

Funding: The project, on which this report is based, was funded by the German Federal Ministry of Education and Research under the number 01LE1806A. Responsibility for the content of this publication lies with the authors.

Institutional Review Board Statement: Not applicable.

Informed Consent Statement: Not applicable.

Data Availability Statement: The datasets generated during and/or analysed during the current study are available in the Institutional Repository of Technische Universität Braunschweig (https: / / doi.org/10.24355/dbbs.084-202201181353-0). 
Acknowledgments: We acknowledge support by the German Research Foundation and the Open Access Publication Funds of Technische Universität Braunschweig.

Conflicts of Interest: The authors declare no conflict of interest.

\section{References}

1. $\quad$ Larson, L.R.; Zhang, Z.; Oh, J.I.; Beam, W.; Ogletree, S.S.; Bocarro, J.N.; Lee, K.J.; Casper, J.; Stevenson, K.T.; Hipp, J.A.; et al. Urban park use during the covid-19 pandemic: Are socially vulnerable communities disproportionately impacted? Front. Sustain. Cities. 2021, 3. Available online: https:/ / www.frontiersin.org/article/10.3389/frsc.2021.710243 (accessed on 15 October 2021). [CrossRef]

2. Spotswood, E.N.; Benjamin, M.; Stoneburner, L.; Wheeler, M.M.; Beller, E.E.; Balk, D.; McPhearson, T.; Kuo, M.; McDonald, R.I. Nature inequity and higher covid-19 case rates in less-green neighbourhoods in the united states. Nat. Sustain. 2021, 4, 1092-1098. [CrossRef]

3. Korpilo, S.; Kajosaari, A.; Rinne, T.; Hasanzadeh, K.; Raymond, C.M.; Kyttä, M. Coping with crisis: Green space use in helsinki before and during the covid-19 pandemic. Front. Sustain. Cities 2021, 3. Available online: https://www.frontiersin.org/article/ 10.3389/frsc.2021.713977 (accessed on 15 October 2021). [CrossRef]

4. Venter, Z.S.; Barton, D.N.; Gundersen, V.; Figari, H.; Nowell, M. Urban nature in a time of crisis: Recreational use of green space increases during the covid-19 outbreak in oslo, norway. Environ. Res. Lett. 2020, 15, 104075. [CrossRef]

5. Askitas, N.; Tatsiramos, K.; Verheyden, B. Estimating worldwide effects of non-pharmaceutical interventions on COVID-19 incidence and population mobility patterns using a multiple-event study. Sci. Rep. 2021, 11, 1972. [CrossRef] [PubMed]

6. Office for National Statistics. How Has Lockdown Changed Our Relationship with Nature? ONA: London, UK, 2021.

7. Asquith, J. People Have Been Flocking to Rural Areas during COVID-19 Lockdowns; Forbes Media: New York, NY, USA, 2020.

8. Gallent, N.; Hamiduddin, I. COVID-19, second homes and the challenge for rural amenity areas. Town Plan. Rev. 2021, 92, 395-402. [CrossRef]

9. Weisbuch, G. Urban exodus and the dynamics of covid-19 pandemics. Phys. A Stat. Mech. Its Appl. 2021, 569, 125780. [CrossRef]

10. Antrop, M. Landscape change and the urbanization process in Europe. Landsc. Urban Plan. 2004, 67, 9-26. [CrossRef]

11. Mumford, L. The City in History Its Origins, Its Transformations, and Its Prospects; Harcourt, Brace \& World: New York, NY, USA, 1961.

12. Dennis, M.; McIntosh, A. Landscape and the city. In Landscape Urbanism and Its Discontents: Dissimulating the Sustainable City; Duany, A., Talen, E., Eds.; New Society Publishers: Gabriola Island, BC, Canada, 2013; pp. 35-56.

13. Dixon Hunt, J.; Willis, P. The Genius of the Place-the English Landscape Garden; MIT Press: Cambridge, MA, USA, 1988; pp. $1620-1820$.

14. Clark, F. Nineteenth-century public parks from 1830. Gard. Hist. 1973, 1, 31-41. [CrossRef]

15. Carlow, V.M. Limits_Space as Resource; Jovis: Berlin, Germay, 2016.

16. Howard, E. To-Morrow: A Peaceful Path to Real Reform; Swan Sonnenschein: London, UK, 1898.

17. Fishman, R. Urban Utopias in the Twentieth Century: Ebenezer Howard, Frank Lloyd Wright, and Le Corbusier; Basic Books: New York, NY, USA, 1977.

18. Reinborn, D. Stadtebau im 19. Und 20. Jahrhundert; Kohlhammer: Stuttgart, Germany, 1996.

19. AIV (Architekten- und Ingenieurverein zu Berlin-Brandenburg e. V.); Bodenschatz, H.; Goebel, B.; Gräwe, C.; Lemburg, P.; Nitschke, M.; Schuster, W. (Eds.) 100 Years of Urban Planning for Greater Berlin; DOM Publishers: Berlin, Germany, 2020 ; Volume 1.

20. Corbusier, L.E. Urbanisme; Cres: Paris, France, 1925.

21. Reichow, H.B. Die autogerechte Stadt_ein Weg aus dem Verkehrschaos; Maier: Ravensburg, Germany, 1959.

22. Sendi, R.; Aalbers, M.; Trigueiro, M. Public space in large housing estates. In Mass Housing in Europe: Multiple Faces Of Development, Change and Response; Rowlands, R., Musterd, S., van Kempen, R., Eds.; Palgrave Macmillan: London, UK, 2009 ; pp. 131-156.

23. Wu, F. Planning for Growth-Urban and Regional Planning in China; Routledge: New York, NY, USA, 2015.

24. Hassenpflug, D. The Urban Code of China; Birkhäuser: Basel, Switzerland, 2012.

25. Lu, D. Remaking Chinese Urban Form-Modernity, Scarcity and Space; Routledge: London, UK, 2006; pp. $1949-2005$.

26. Daniel, B.A. The Uses of Planning History In China. In The Routledge Handbook of Planning History; Routledge: Milton Park, UK, 2017.

27. Baihao, L.; Guo, J.; Huang, Y. A Historical Study on the Paradigm of Early-modern City Planning of Shanghai: 1843 1949. Urban Plan. Forum 2006, 6, 83-91.

28. Junhua, L.; Lü, J.; Rowe, P.G.; Zhang, J. (Eds.) Modern Urban Housing in China; Prestel: Munich, Germany, 2001; pp. 1840-2000.

29. Jianhong, D. History of Chinese Urban Construction; China Architecture \& Building Press: Beijing, China, 2004.

30. Zhang, Y.; You, J.; Chen, A.; Zhou, Y.; Wang, X. A Review of Development and Application of Urban Green Space System in China; Sichuan Academy of Forestry: Chengdu, China, 2010; pp. 68-73. [CrossRef]

31. Huang, B.; Dong, N. Study on Differentiation of Parks' Recreation Supply and Demand between New Town and City Center: A Case Study of Ziqidonglai Park and Fuxing Park. Shanghai Urban Plan. Rev. 2016, 4, 56-60.

32. Jin, Y.; Chen, L.; Tao, N.; Zou, K. Urban Park Boundary Space Optimization Strategy for Human Needs in Life Circle. J. Chin. Urban For. 2020, 6, 21-25.

33. Newman, P.; Trevor, H. A review of urban density models: Toward a resolution of the conflict between populace and planner. Hum. Ecol. 1981, 9, 269-303. [CrossRef] 
34. WOHA. Kampung Admiralty; WOHA: Singapore, 2020; Available online: https://woha.net/project/kampung-admiralty/ (accessed on 10 May 2021).

35. Poh, L.N.K. Kampung Admiralty: Green Infrastructure Bringing People Together; Ramboll: Singapore, 2020; Available online: https:/ / ramboll.com/projects/singapore/kampung-admiralty (accessed on 12 October 2021).

36. Menz, S.; Rassia, S.; Jiang, Y.; Kumar, A.; Bastianello, D.; Glaser, M.A.; Graham, C.C. Public Space Evolution in High-Density Living in Singapore. Ground and Elevated Public Spaces in Public Housing Precincts; Future Cities Laboratory, ETH Singapore SEC Ltd.: Singapore, 2014.

37. Grüntuch-Ernst, A.; IDAS (Institute for Design and Architectural Strategies). Hortitecture-The Power of Architecture and Plants; Jovis: Berlin, Germany, 2018.

38. Oh, E. Vo trong nghia architects' diamond lotus brings greenery to ho chi minh city. ArchDaily 2015. Available online: https: / / www.archdaily.com/774547/ (accessed on 15 December 2021).

39. MVRDV. Green Dreams; MVRDV: Rotterdam, The Netherlands, 2021; Available online: https://mvrdv.nl/themes/6/sustainability (accessed on 10 December 2021).

40. Niland, J. Benthem Crouwel Wins in Prague with Mixed-Use Green Design Called Valley; Bustler: Pasadena, CA, USA, 2021.

41. OMA. Bajes Kwartier; OMA: Rotterdam, The Netherlands, 2021; Available online: https:/ /www.oma.com/ projects/bajes-kwartier (accessed on 15 November 2021).

42. Haines, V.A. Energy and urban form: A human ecological critique. Urban Aff. Q. 1986, 21, 337-353. [CrossRef]

43. Hurlimann, A.; Moosavi, S.; Browne, G.R. Urban planning policy must do more to integrate climate change adaptation and mitigation actions. Land Use Policy 2021, 101, 105188. [CrossRef]

44. Tian, P.; Li, J.; Cao, L.; Pu, R.; Wang, Z.; Zhang, H.; Chen, H.; Gong, H. Assessing spatiotemporal characteristics of urban heat islands from the perspective of an urban expansion and green infrastructure. Sustain. Cities Soc. 2021, 74, 103208. [CrossRef]

45. Li, L.; Uyttenhove, P.; van Eetvelde, V. Planning green infrastructure to mitigate urban surface water flooding risk-A methodology to identify priority areas applied in the city of ghent. Landsc. Urban Plan. 2020, 194, 103703. [CrossRef]

46. Sharifi, A. Co-benefits and synergies between urban climate change mitigation and adaptation measures: A literature review. Sci. Total Environ. 2021, 750, 141642. [CrossRef]

47. Ekkel, E.D.; de Vries, S. Nearby green space and human health: Evaluating accessibility metrics. Landsc. Urban Plan. 2017, 157, 214-220. [CrossRef]

48. Annerstedt van den Bosch, M.; Mudu, P.; Uscila, V.; Barrdahl, M.; Kulinkina, A.; Staatsen, B.; Swart, W.; Kruize, H.; Zurlyte, I.; Egorov, A.I. Development of an urban green space indicator and the public health rationale. Scand. J. Public Health 2016, 44, 159-167. [CrossRef]

49. Pietilä, M.; Neuvonen, M.; Borodulin, K.; Korpela, K.; Sievänen, T.; Tyrväinen, L. Relationships between exposure to urban green spaces, physical activity and self-rated health. J. Outdoor Recreat. Tour. 2015, 10, 44-54. [CrossRef]

50. UN-DESA. World Population Prospects 2019—Online Edition; United Nations Department of Economic and Social Affairs Population Division: New York, NY, USA, 2019.

51. SenStadt, Senate Department for Urban Development and the Environment and Urban Catalyst. Berlin Strategy-Urban Development Concept Berlin 2030; Senate Department for Urban Development and the Environment: Berlin, Germany, 2015.

52. Senate Chancellery Berlin. Senate Chancellery Berlin. Senate Department for Urban Development and Johanssen + Kretschmer Strategische Kommunikation GmbH. In Berlin Strategie 3.0-Solidarisch, Nachhaltig, Weltoffen; Senate Chancellery: Berlin, Germany, 2021.

53. Qingdao Urban Planning Committee and Qingdao Urban Planning \& Design Institute (Ed.) Urban Masterplan Qingdao (2021-2035); Qingdao Municipal People's Government: Qingdao, China, 2020.

54. Oswald, P. Berlin, Stadt ohne Form. Strategien einer anderen architektur; Prestel: München, Germany, 2000.

55. Bodenschatz, H. Berlin Urban Design-A Brief History of a European City, 2nd ed.; DOM: Berlin, Germany, 2013.

56. Von Moltke, W.V. The evolution of berlin's urban form through history, illustrated by selected examples. In Views of Berlin: From a Boston Symposium; Kirchhoff, G., Ed.; Birkhäuser Boston: Boston, MA, USA, 1989; pp. 277-297.

57. Li, D.; Zhou, Y. Historical Study on the Relationship between Urban Planning and Urban Development, a Case of Qingdao in Modern Times. New Archit. 2007, 2, 16-22.

58. NBS National Bureau of Statistics of the People's Republic of China. Population by Administrative Units on 1 November 2020 National Bureau of Statistics of P.R.: Beijing, China, 2021.

59. Chong, L. The Contemporary Development of Urban Space-The Perspective of Civil Society's Participation in Urban Planning; BauhausUniversität Weimar: Weimar, Germany, 2007.

60. Wikipedia Contributors. Wikipedia: The Free Encyclopedia; Wikimedia Foundation, 2021. Available online: https://en.wikipedia. org/wiki/Qingdao (accessed on 15 April 2021).

61. Cheshmehzangi, A. China's New-type Urbanisation Plan (NUP) and the Foreseeing Challenges for Decarbonization of Cities: A Review. Energy Procedia 2016, 104, 146-152. [CrossRef]

62. Qingdao Bureau foresty development plan. The 14th Five Year Plan for Forestry Development Plan in Qingdao 2021-2025; Qingdao Bureau of Foresty Development Plan: Qingdao, China, 2021.

63. Qingdao Municipal Environmental Protection Bureau. General Plan of Urban Environment of Qingdao City (2016-2030); Qingdao Municipal Environmental Protection Bureau: Qingdao, China, 2016. 
64. Qingdao Bureau of Natural Resources and Planning. The 13th Five Year Plan for National Economic and Social Development in Qingdao 2016-2020); Qingdao Bureau of Natural Resources and Planning: Qingdao, China, 2016.

65. Qingdao Bureau of Water Authority. Overall Plan for Water Security in Qingdao; Qingdao Bureau of Water Authority: Qingdao, China, 2016.

66. Qingdao Development and Reform Commission. Qingdao General Plan (2011-2020); Qingdao Development and Reform Commission: Qingdao, China, 2011.

67. Qingdao Development and Reform Commission. Qingdao Construction International Bay Area Urban Path Indicators; Qingdao Development and Reform Commission: Qingdao, China, 2016.

68. Wan, Z.; Wang, A.; Wang, Z. End of an Era in China's Urbanization E Beginning of a Neww One; Wang, Z., Wan, Z., Eds.; Pekinology: Beijing, China, 2021; Available online: https:/ / pekingnology.substack.com/p/end-of-an-era-in-chinas-urbanization (accessed on 20 October 2021).

69. Cooper, B. China's 14th Five-Year Plan (2021-2025) Report; Hill+Knowlton Strategies: Beijing, China, 2021.

70. ESRI. Arcgis Pro 2.8.0; ESRI: Redlands, CA, USA, 2021.

71. Landesvermessung und Geobasisinformation Brandenburg. Alkis Brandenburg; Berlin Senate Department for Urban Development und Housing: Frankfurt, Germany, 2021.

72. Geoportal Berlin. Alkis Berlin; Berlin Senate Department for Urban Development und Housing: Berlin, Germany, 2021.

73. ESRI. Topographic [Basemap]. Scale Not Given. World Topographic Map; ESRI: Redlands, CA, USA, 2012.

74. OpenStreetMap Contributors (Ed.) Openstreetmap: Qingdao. 2021. Available online: https://www.openstreetmap.org/search? query=qingdao (accessed on 15 February 2021).

75. Esri. World Imagery Basemap Low Resolution 15m Imagery; ESRI: Redlands, USA, 2021.

76. ESA. Sentinel multispectral satellite imagery Sentinel 2b (20201217); ASF DAAC: Fairbanks, AK, USA, 2021.

77. ESA. Sentinel multispectral satellite imagery Sentinel 2a (20210111); ASF DAAC: Fairbanks, AK, USA, 2021.

78. Bondarenko, M.; Kerr, D.; Sorichetta, A.; Tatem, A.J. Census/Projection-Disaggregated Gridded Population Datasets, Adjusted to Match the corresponding UNPD 2020 estimates, for 183 countries in 2020 using Built-Settlement Growth Model (BSGM) Outputs; WorldPop: Southampton, UK, 2020.

79. Baidu. Baidu Maps. Available online: https://map.baidu.com/@13387463.84509341,4304347.144603039,11.76z/ (accessed on 15 March 2021).

80. Google. Google maps/google earth. Mountain Google: View. 2021. Available online: http://maps.google.com (accessed on 15 November 2021).

81. MLUK; Ministry of Agriculture; Environment and Climate Protection Brandenburg; SenStadt; Senate Department for Urban Development und Housing Berlin. Gemeinsamer Landesentwicklungsplan für den engeren Verflechtungsraum Brandenburg-Berlin (lep ev); Ministry of Agriculture, Environment and Climate Protection Brandenburg: Potsdam, Germany; Senate Department for Urban Development und Housing Berlin: Berlin, Germany, 1998.

82. Amt für Statistik Berlin-Brandenburg. Raumbezüge: Hauptstadtregion Berlin-Brandenburg (here: Berlin + Umland); Amt für Statistik Berlin-Brandenburg: Potsdam, Germany, 2021; Available online: https:/ /www.statistik-berlin-brandenburg.de/raumbezuege (accessed on 1 November 2021).

83. ESRI. China Province Boundaries 2020; ESRI: Redlands, CA, USA, 2021.

84. Carlow, V.M.; Mumm, O.; Neumann, D.; Schneider, A.-K.; Schröder, B.; Sedrez, M.; Zeringue, R. Topoi-A method for analysing settlement structures and their linkages in an urban rural fabric. Environ. Plan. B Urban Anal. City Sci. 2022. [CrossRef]

85. Montero, G.; Tannier, C.; Thomas, I. Delineation of cities based on scaling properties of urban patterns: A comparison of three methods. Int. J. Geogr. Inf. Sci. 2021, 35, 919-947. [CrossRef]

86. Chaudhry, O.; Mackaness, W.A. Automatic identification of urban settlement boundaries for multiple representation databases. Comput. Environ. Urban Syst. 2008, 32, 95-109. [CrossRef]

87. Pumain, D.; Eric, D.; Bretagnolle, A. From theory to modelling: Urban systems as complex systems. Cybergeo 2006, 335. [CrossRef]

88. Zeringue, R.; Mumm, O.; Carlow, V.M. Green Densities-Urban Core Area and Associated Building Stock, Population and Vegetation in the Urban Regions of Berlin (Germany) and Qingdao (China) [Data Set]; TU Braunschweig: Braunschweig, Germany, 2022. [CrossRef]

89. WorldPop, S.D.I. Worldpop open population repository; WorldPop SDI: Southampton, UK, 2021; Available online: https:/ wopr. worldpop.org (accessed on 15 November 2021).

90. Weier, J.; Herring, D. Measuring Vegetation (Ndvi \& Evi); The Earth Observatory: Greenbelt, MD, USA, 2000. Available online: https:/ / earthobservatory.nasa.gov/features/MeasuringVegetation/measuring_vegetation_2.php (accessed on 5 August 2021). 